University of Rhode Island

DigitalCommons@URI

Open Access Master's Theses

1992

\title{
Flexibility in the U.S. Medical Instrument and Supply Industry
}

Huaqi Yuan

University of Rhode Island

Follow this and additional works at: https://digitalcommons.uri.edu/theses

\section{Recommended Citation}

Yuan, Huaqi, "Flexibility in the U.S. Medical Instrument and Supply Industry" (1992). Open Access Master's Theses. Paper 752.

https://digitalcommons.uri.edu/theses/752

This Thesis is brought to you for free and open access by DigitalCommons@URI. It has been accepted for inclusion in Open Access Master's Theses by an authorized administrator of DigitalCommons@URI. For more information, please contact digitalcommons-group@uri.edu. 


\section{Flexibility in the U.S. Medical Instrument and supply Industry}

\section{By}

Huaqi Yuan

A Research Project Submitted in Partial Fulfillment of the Requirements

for the Degree of Master of Community planning The University of Rhode Island

$$
\text { May, } 1992
$$




\section{Master of Community Planning}

\section{Research Project of}

Huaqi Yuan

APPROVED:
Major Professor

ACKNOWLEDGED: Director

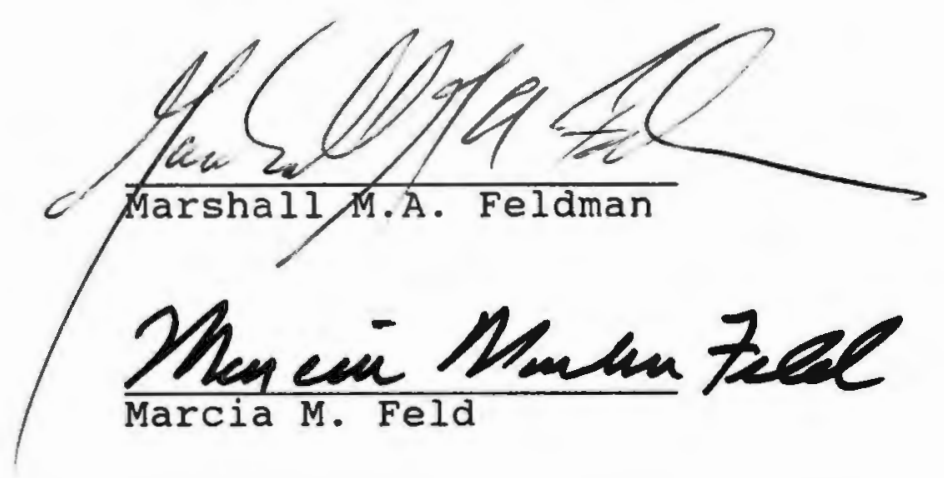




\section{Abstract}

This master's research project is a basic study of flexibility in the U.S. medical instruments and supply industry.

Chapter 1 reviews the literature on the debate over flexibility and its relevance to the medical instruments and supply industry.

Chapter 2 briefly introduces the methodology used in this research.

Chapter 3 reviews factors influencing the development of the industry.

Chapter 4 profiles the medical supply industry in the us today.

Chapter 5 analyzes flexibility in the industry by applying the methodology discussed in Chapter 2 .

Chapter 6 discusses policy implications. 


\section{Acknowledgements}

I am indebted to many individuals whose encouragement, guidance and support made it possible for me to finish this project. special thanks are given to my major professor, Dr. Marshall A. Feldman of Community Planning Department. Without his understanding of the issue, helpful comments and direction in the production of this project, it would be hard to imagine how this research could have been completed.

Thanks are also extended to Dr. Howard H. Foster, Jr., former Chair of the Department of Community Planning, who first introduced me to the University of Rhode Island's planning program and is also as reader for this project. His generosity, guidance and friendship helped make my time easier in this university.

Thanks are also bestowed to Dr. Richard McIntyre, Department of Economics, for his help as reader for this project.

Thanks are also offered to my fellow students. Through the discussions and arguments in the classroom and the group projects, it certainly sharpened my understanding of the discipline of planning. Kathleen Barton, Curt Bellavance, Michael Fawcett and James Moran especially deserve my sincere gratitude for their valuable help in both academic and social aspects. 
Table of contents

Abstract................................ ii

Acknowledgements........................ iv

Table of contents......................... v v

List of Tables.......................... vii

List of figures......................... viii

Chapter one - Introduction to the Flexibility Debate. 1

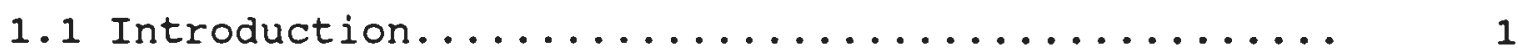

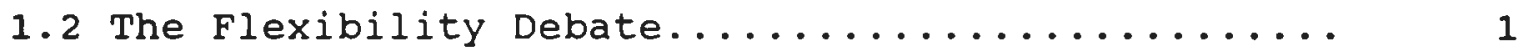

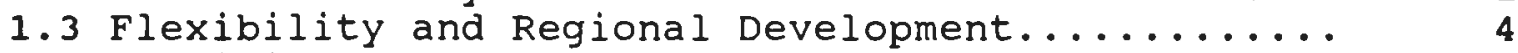

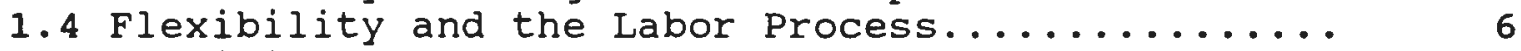

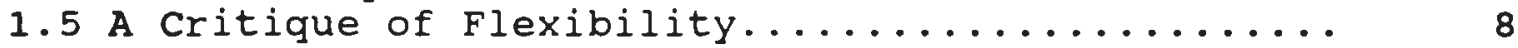

1.6 Flexibility and the Medical Instruments

and supply Industry.................... 10

Chapter Two - Methodology.................... 13

Chapter Three - Historical Development of the Medical

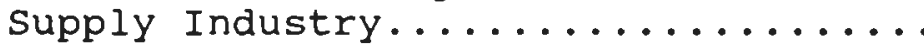

3.1 The Medical Instrument and Supply Industry...... 15

3.2 Factors Affecting the Development of the Industry 15

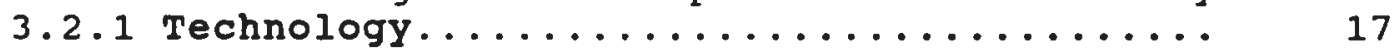

3.2 .2 Government Regulations................. 18

3.2.3 Foreign Trade and Foreign competition..... 22

3.2 .4 other Factors....................... 24

3.3 Value Added, Value of Shipments and Employment in

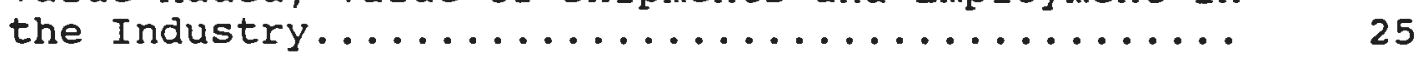

Chapter Four - The Medical Supply Industry Today..... 31

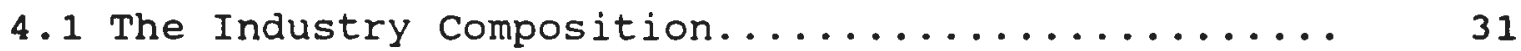

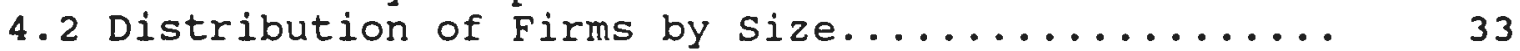

4.3 Spatial Distribution of the Medical

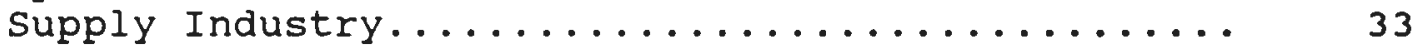

4.4 Description of Some Leading Companies........... 39

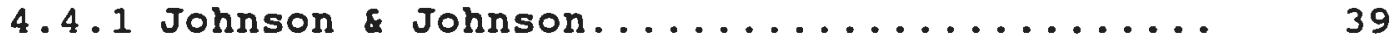

4.4 .2 Abbott Laboratories................... 40

4.4 .3 Baxter International Inc................ 41

4.4 .4 Becton Dickison co................ 43

4.4 .5 Bausch Lomb Inc................... 43 
Table of contents (cont.)

Chapter Five - Flexibility in the Medical Supply Industry................

5.1 Strategies Adopted by the Industry in General....

5.1.1 Improving and Advancing Technology

to Reduce costs.................... 45

5.1 .2 Penetrating into Drug Production.......... 48

5.1 .3 offering Long-Term Contracts to Maintain

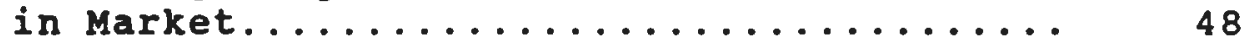

5.1.4 Targeting at Nonhospital Markets........

5.1 .5 Targeting Geriatric Market............. 49

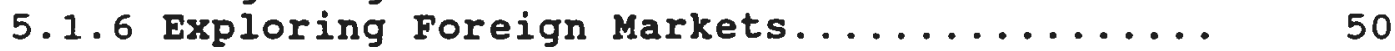

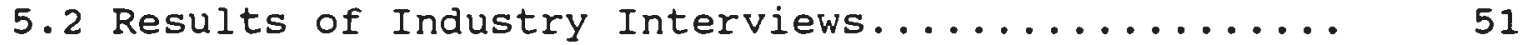

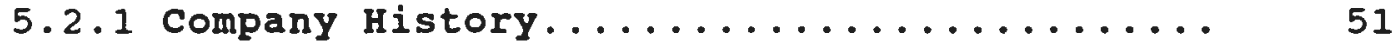

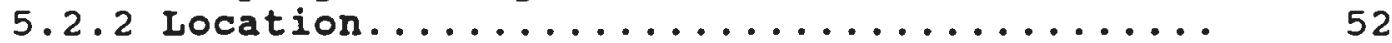

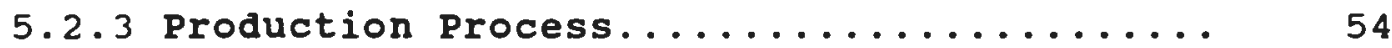

5.2 .4 Labor........................... 57

5.3 Specialization Ratio, Labor Turnover Rate and Change of Geographical Distribution of the Industry..... 59

5.4 Is Flexibility Occurring in the Medical Supply

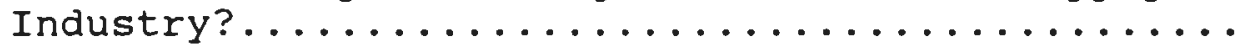

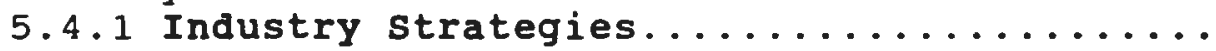

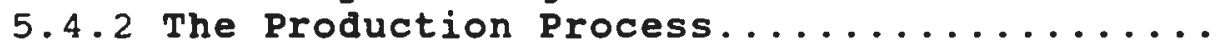

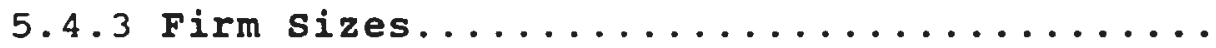

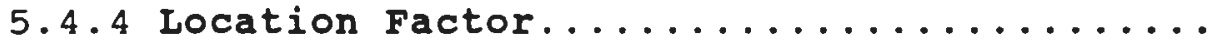

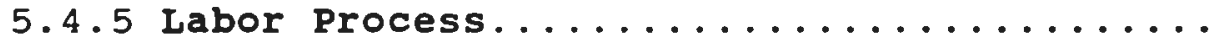

Chapter Six - Policy Implications............... 71

Bibliography $\ldots \ldots \ldots \ldots \ldots \ldots \ldots \ldots \ldots \ldots \ldots \ldots$ 


\section{List of Tables}

Table 1.1 Fordism vs Flexibility............. 2

Table 3.1 Definition of the Medical Supply Industry.... 16

Table 3.2 Trade Data: The Medical Supply Industry..... 23

Table 3.3 The Medical Supply Industry in Manufacturing. 26

Table 3.4 Comparison of the Medical Supply Industry and

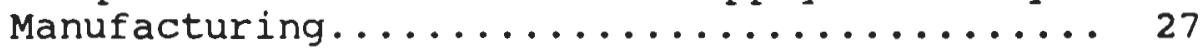

Table 3.5 Comparison of the Medical Supply Industry with other Instrument Industries............ 29

Table 4.1 Composition of the Medical Supply Industry... 32

Table 4.2 Total Numbers Employed in the Medical Supply Industry...................... 34

Table 4.3 Regional Distribution of the Medical Supply Industry Establishments (1987) ......... 35

Table 4.4 Geographical Pattern of the Medical Supply Industry Employment (1987) ............ 37

Table 4.5 Population by Regions (1987) .......... 38

Table 5.1 Specialization Ratio for the Medical Supply Industry........................... 60

Table 5.2 Number of Production Worker in the Medical Supply Industry.................62

Table 5.3(a) Geographical Patterns of the Medical Supply Industry Establishments.........6 63

Table 5.3(b) Geographical Patterns of the Medical Supply Industry Employment............ 64

Table 5.3(c) Geographical Patterns of the Medical Supply Industry Value Added........... 65

Table 5.4 Population by Regions (1977-1987)........ 67 


\section{List of Figures}

Figure 1.1 Labor Market structures under condition of Flexible Accumulation................. 7 


\section{Chapter One}

\section{Introduction to the Flexibility Debate}

\subsection{Introduction}

since the early $1980^{\prime} \mathrm{s}$, a debate has raged in planning, economics, geography, and political science about changes in capitalist industry's organization. The dazzling variety of industrial changes during the last quarter century make it difficult to grasp the controversy. However, this debate centers on a series of dichotomies: batch vs mass production, disintegrated vs integrated firms, economies of scope vs economies of scale, and "flexible specialization" vs "rigid fordist production". The critical argument focuses on (1) whether or not there is a new regime of flexible accumulation (conventionally called flexibility) and, (2) if so, whether or not this new regime could replace or substitute for the regime of Fordist accumulation (conventionally called Fordism) and become the dominant form of economic organization in market society.

\subsection{The Flexibility Debate}

To understand this debate, one must distinguish the main features of these two regimes. Albrechts and swyngedoun (1988:9-10) point out five elements for comparing these two regimes: the production process, labor, space, the state, and ideology. The main points of their comparison are summarized in Table 1.1 . 
Table 1.1

Fordism vs Flexibility

Fordism

Mass production

Uniform

Supply driven

Vertical integration
Flexibility

The

Production

Process

\begin{tabular}{|c|c|c|}
\hline & Vertical integration & $\begin{array}{l}\text { Vertical } \\
\text { disintegration }\end{array}$ \\
\hline Labor & $\begin{array}{l}\text { Single task } \\
\text { Job specialization } \\
\text { No job training } \\
\text { No job security }\end{array}$ & $\begin{array}{l}\text { Multiple tasks } \\
\text { No job demarcation } \\
\text { Long-on job training } \\
\text { High job security for } \\
\text { permanent workers }\end{array}$ \\
\hline & Decentralization & $\begin{array}{l}\text { Cluster \& } \\
\text { Agglomeration }\end{array}$ \\
\hline Space & $\begin{array}{l}\text { Suburbanization } \\
\text { Segmented labor markets }\end{array}$ & $\begin{array}{l}\text { Urban Center } \\
\text { Labor market } \\
\text { diversified }\end{array}$ \\
\hline The state & $\begin{array}{l}\text { Regulation } \\
\text { Rigidity } \\
\text { Socialized welfare } \\
\text { Firm-financed R\&D } \\
\text { Indirect intervention } \\
\text { in market }\end{array}$ & $\begin{array}{l}\text { Deregulation } \\
\text { Flexibility } \\
\text { Privatized welfare } \\
\text { State-financed R\&D } \\
\text { Direct intervention } \\
\text { in market }\end{array}$ \\
\hline Ideology & $\begin{array}{l}\text { Modernism } \\
\text { Socialization } \\
\text { Rationalism } \\
\text { Totality/structural } \\
\text { Specificity/Adaptation } \\
\text { reform }\end{array}$ & $\begin{array}{l}\text { Post-Modernism } \\
\text { Individualization } \\
\text { Deconstructionism }\end{array}$ \\
\hline
\end{tabular}

small batch

Flexible

Demand driven

Vertical

Multiple tasks

Long-on job training High job security for
No job demarcation

Agglomeration

Urban Center

Labor market

Deregulation

Flexibility

Privatized welfare

State-financed R\&D

Direct intervention

in market

Post-Modernism

Individualization

Socialization

Deconstructionism

Source: Albrechts \& Swyngedoun (1988:9-10). 
Many scholars (Feldman, 1989a, 1989b, 1989c, 1990; Piore \& Sabel 1984; Scott 1988; etc.) argue that this debate is rooted in the theoretical territory of the French Regulationist school. This school of thought argues that stable growth in capitalist economies requires an extensive assortment of non-market rules, regulations, norms, organizations and operations which collectively form a "regime of accumulation". Without such a presumption, the whole debate would become moot.

Under this assumption, Piore and Sabel first presented their seminal and stimulating The Second Industrial Divide in 1984, and pioneered the dispute over flexibility. In their opinion, Fordism failed because it could no longer hande the growing volatility and instability generated by escalated international competition. The large and stable markets that mass production needs to achieve economies of scale hardly exist today. Therefore, a new type of production method, "flexible specialization", a term indicating spatially dense networks of relating small, vertically disintegrated firms, is emerging to adjust the old production system to the new environment.

Four traits characterize flexible specialization (FS) (Sabel \& Zeitlin, 1985:144, Feldman \& Yuan 1990:4). First, FS produces a wide range of products for highly differentiated markets so that changing demands can be met. Second, FS is characterized by small and medium-sized firms. Third, FS is 
technologically dynamic, as reflected in the firm's ability to alter product mix and to introduce new product and process innovations. Finally, firms engaged in FS cooperate with each other and benefit from external economies of scale which support vertically disintegrated firms. Planners are particularly interested in: (1) flexibility and regional development and (2) flexibility and the labor process.

\subsection{Flexibility and Regional Development}

Flexibility and its relationship to regional development have attracted the attention of theoreticians from the very beginning. Scott (1988) argues that a transition has occurred during the last decade or so and that fordism is being supplanted by more flexible forms of production. Scott points out that the mode of social regulation that sustained fordist production is no longer strong enough to pin up this old regime. Factors contributing to this are: (1) endemic outflow of capital from core regions, (2) international competition, particularly from Japan and newly industrializing countries, (3) stagflation, which is reflected in declining industrial productivity, rising unemployment, and the fiscal inability to maintain huge public expenditures to keep the Keynesian welfare state in operation. Hence:

(a) production systems are displaying signs of a deepening division of labor and an expansion of external economies of scale, (b) that local labor 
markets are becoming increasingly less rigid in structure, and (c) that rapid reagglomeration of production has been occurring as a consequence (Scott, 1988:185).

Scott's analysis sheds light on the relationship between flexible production and regional development and enhances further investigation of policy implications for this new form of organization. More specifically, he hypothesizes that flexibility will be found in three industrial sectors: revivified artisanal and design-intensive industries; high technology industries and their associated phalanxes; and services, mostly business services.

Almost at the same time, sabel (1988) shared scott's view of the emergence of flexible production regions. He asserted that the move toward more and more flexible responses may lead to the reconsolidation of the region as an integrated unit of production. However, he took one step further to discuss potential problems with this new form of production. He believed that even if regional economies do emerge, they will find it difficult to survive without the aid of national institutions. Flexible firms may be better able to survive the poor economy than those of mass production. However, it does not necessarily mean that they will be immune from failure. Regions lagging behind still need assistance from the prosperous areas, and a new national resource allocation system would be needed to achieve that. 


\subsection{Flexibility and the Labor Process}

A second area of discussion is the relationship between flexibility and the labor process. Schoenberger (1988) asserted that while there may be gains in job security and union relations as flexibility requires more participation of workers, flexible specialization demands extremely flexible work schedules, for example, part-time work will rise with the requirements of increasing flexibility.

Harvey (1989) argues that flexibility rests on the labor process and it has led to the radical restructuring of the labor market. He states:

"Faced with strong market volatility, heightened competition, and narrowing profit margins, employers have taken advantage of weakened union power and the pools of surplus (unemployed or underemployed) laborers to push for much more flexible work regimes and labor contracts" (Harvey, 1989:150)

Under this circumstance, the labor market takes on a core-periphery pattern as portrayed in Figure 1.1. "The core... is made up of employees with full time, permanent status and is central to the long term future of the organization"" (Harvey, 1989:150). It is a relatively small group. However, the periphery includes two rather different sub-groups.

"The first consists of full-time employees with skills that are readily available in the labor market, such as clerical, secretarial, routine and lesser skilled manual workers. With less access to career opportunities, this group tends to be characterized by high labor turnover.... The second periphery group 'provides even greater numerical flexibility and includes part-timers, casuals, 


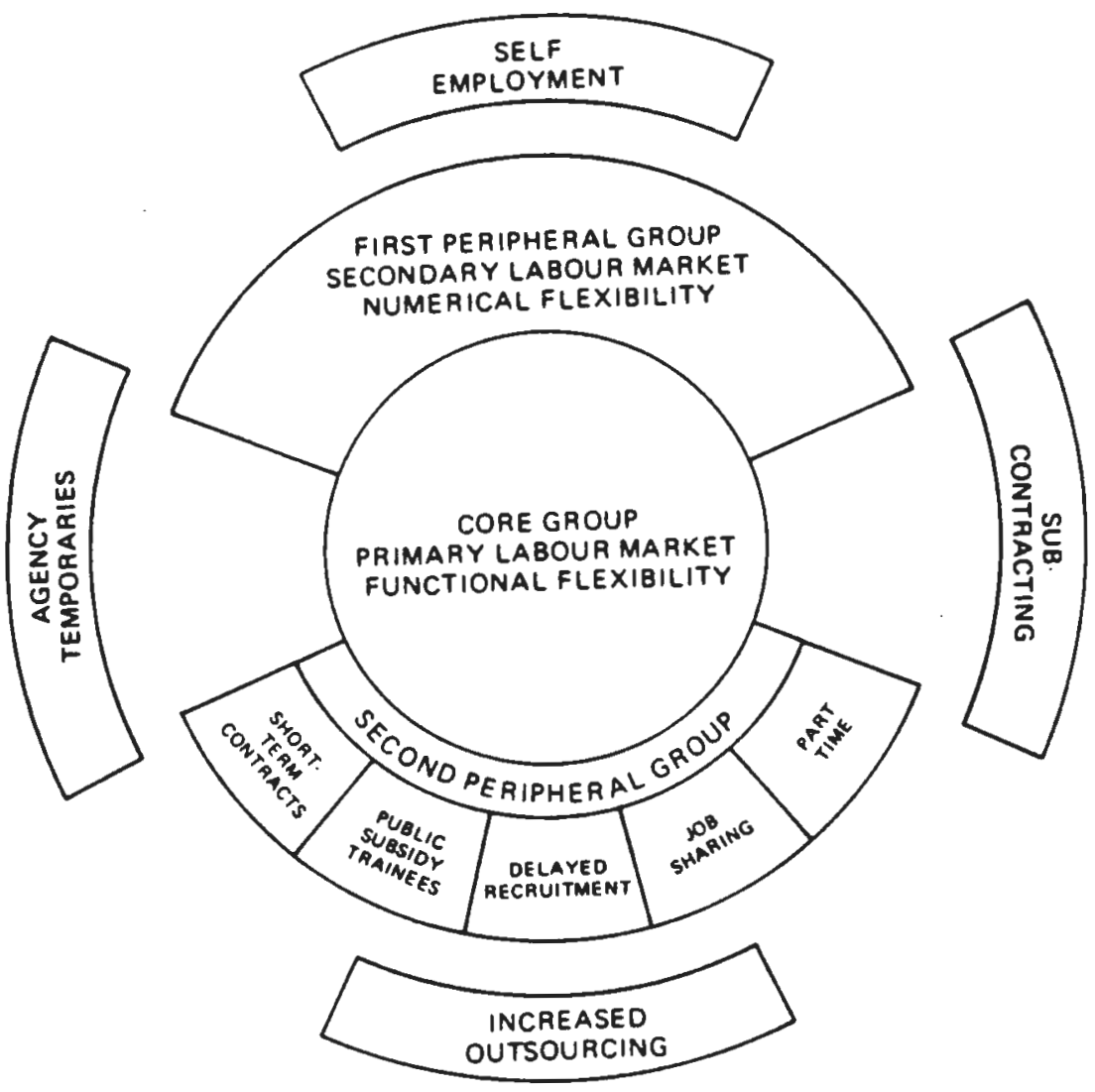

Figure 1.1 Labor Market structures under Conditions of Flexible Accumulation

Source: Harvey, D (1989:150) 
fixed term contract staff, temporaries, subcontractors and public subsidy trainees, with even less job security that the first peripheral group.'" (Harvey, 1989:150).

This new form of labor organization makes collective action more difficult since it fosters extreme individualism. Harvey's analysis opens another channel for looking at flexibility.

\subsection{Critiques of the Flexible Specialization Thesis}

A number of critical questions have been raised regarding flexible specialization. These criticisms center around three issues;

1. Phenomenon or Essence

Storper (1989) questions the existence of a new regime of flexibility." He asserts that much flexible production is nothing more than specific technological and organization strategies. Although flexible specialization appears to be spreading, there are still many mass producers in operation. Therefore, a deeper study regarding this new form of capitalist production should be done to examine the underlying logic of recent socioeconomic change.

1 Storper basically raises the question of whether flexible production is, in fact, just a manifestation of the "phenomenon" or instead, the essence of "nature". 
2. Fordism is still alive

Sayer (1987) argues that Japan should receive more attention and that fordism is still alive. He does so on four grounds. First, even if one accepts that postwar capitalism is fordist and that capitalism is currently in crisis, we cannot logically deduce that fordism is therefore in crisis because fordism is not necessarily the cause of capitalism's crises.

Second, some alleged inherent limitations of fordism are really not limitations. Fordism did not create improved working conditions so that labor resistance builds up. Notwithstanding "labor resistance did build up in a few fordist sectors, particularly the car industry, but less so in others, and no more so than in many nonfordist sectors" (Sayer, 1987:669). Also, Japanese mass production has not failed. The evidence that the rate of productivity change in mass production is declining in fordist sectors is inconclusive.

Third, many current problems have nothing to do with the labor process, but with the relative lack of new sectors or products. Fordism might still flourish if technological innovation is successful.

Fourth, if small-batch production is still resistant to automation and rapid increases in productivity, the crisis of small-batch production rather than the mass production sector could be at the root of the current crisis. 
3. The question of space

Amin (1989) argues that the flexibility debate treats space in a partial and uni-directional, evolutionary way. The assumption of:

"spatial agglomeration and the local containment of the functional division of labor best respond to the organizational demands of flexible specialization.... (this) underplays the existence of significant differences in the characteristics and origins of various contemporary industrial districts, such as the importance of large retailers and subcontractors as key actors in some areas, or small firms networks in other areas" (Amin, 1989:18).

Amin depicts FS's uni-directional evolution as counter historical. He mentioned:

"Accurate or not, this approach nonetheless ends up treating the modern local industrial complex as a point of arrival, paying little attention to the forces which are likely to reshape or even threaten their contemporary evolutionary status" (Amin, $1989: 18$ ).

\subsection{Flexibility and the Medical Instruments and supply Industry}

The two most often cited proximate causes of flexibility's growing importance are technology and economic instability (Feldman, 1989b:12). New technologies have greatly reduced the cost of flexible production processes and hence have made entirely new flexible production systems possible (Scott 1988, Feldman, 1989b). Moreover, scott (1988) stated that the new regime of flexible specialization is founded in three major industrial sector. One of them is the high technology or "leading edge" industries. Economic instability 
caused mainly by intensified international competition has made the large and stable markets mass production needs to achieve economies of scale hardly exist (Piore \& Sabel, 1984, Scott, 1988, Feldman, 1989b). Therefore, firms adopt flexible production methods that allow them to respond quickly to changing economic situations.

The American medical supply industry has been considered as the global leader in the production of medical instruments and supplies due to its continuous and ambitious development of new, high-tech, sophisticated equipment. New technology has played a significant role in the development of the industry $(S \& P, 1986,1987,1988,1990,1991)$. On the other hand, the industry also faced more and more intensive international competition from Japan, Germany, West European countries and other newly industrialized countries since these countries have also launched huge $R \& D$ programs in the development of high-tech medical devices. Obviously, technology and international competition have strongly influenced the development of this industry. studying the medical supply industry and its relationship with flexibility would certainly provide further understanding of flexibility and its causes and it, in turn, would enhance the whole academic debate.

Furthermore, the study of medical supply industry and its relationship to the flexibility debate has practical merit. The medical supply industry has undergone substantial 
development during the last two decades. It has maintained a double-digit average growth rate $(12.85 \%)$ in industrial shipments, which has outpaced the growth of the manufacturing sector as a whole (7.55\%) (see Table 3.4). It also created many job opportunities, its average employment growth rate during last two decades has reached $5.33 \%$, which also outpaces the growth of the manufacturing sector (0.45\%) (also see Table 3.4). Moreover, the industry is also considered as a tradesurplus earner. During the last two decades or so, the tradesurplus created by the industry has increased from $\$ 210$ million to $\$ 2,109$ million, representing again a double-digit growth rate $(13.67 \%$ ) (see Table 3.2 ).

The question is whether or not the strong performance of the medical supply industry is attributable to flexible specialization as the flexibility theory itself claims. certainly, the answer to this question will help the development of other industries, as well as the medical supply industry itself, by helping key actors know better about their situation and adopt strategies appropriate for their industries' development. 
Chapter Two

Methodology

Previous research on flexibility had the problem of overwhelmingly relying on case studies. However, little, if any systematic selection process was used to choose the industries for case studies. This research project, nonetheless, was derived from a systematic process.

In the initial period of research, national data were collected and analyzed to identify industries in which flexibility seemed to be increasing. Data for the this period mainly came from Small Business Data Base (SBDB) of U.S. Small Business Administration from 1976-1984. A number of indicators were constructed which included the number of specialist independent establishments, employment per establishment, and total industry employment. Changes in these indicators were measured by using regression residuals method (analyzed at the four-digit SIC level) (Feldman \& Yuan, 1990). The results of this analysis showed that several industries appeared to be becoming more flexible and vertically disintegrated. We choose three industries for in-depth study. These industries are: textile finishing, aircraft parts, and the medical instruments and supply industry.

The second portion of the study involved analysis of secondary data related to the industry, face-to-face interviews with firms in the industry, and the study of related academic literature and case studies on the industry. 
Secondary data included come from: The Annual survey of Manufactures. The Census of Manufactures, standard and Poor's Industrial Surveys, Moody's Industrial Manual, and The Wall Street Journal.

Principals at five medical supply firms were interviewed. Questions related to the company's history, production process, location, and labor relation were asked.

Finally, all this information was collected and analyzed to present a detailed study of the industry and its relationship to flexibility. They will be presented in chapter 5. It is intended to answer the question of whether or not flexibility is occurring in the medical supply industry. 


\section{Chapter Three}

\section{Historical Development of the Medical Instrument and supply Industry}

\subsection{The Medical Instrument and Supply Industry}

The medical instrument and supply industry (hereafter referred to the medical supply industry) in this study, refers to the category of "Surgical, Medical, and Dental Instruments and Supplies" defined by the 1987 standard Industry Classification Manual (USOMB,1987:250-252) to include the following 4-digit SIC codes: ${ }^{2}$ (Definitions for these categories are given in Table 3.1.)

SIC 3841: Surgical and Medical Instruments

SIC 3842: Surgical Appliances and Supplies

SIC 3843: Dental Equipment and Supplies

SIC 3844: X-Ray Apparatus and Tubes

SIC 3845: Electromedical Equipments

\subsection{Factors Affecting the Development of the Industry}

The medical supply industry has been influenced by factors such as technology, government regulations, foreign trade and competition, and other factors like demography, litigation, and the incidence of new diseases. Each of these factors are discussed below.

${ }^{2}$ SIC 3844 and SIC 3845 did not exist until 1987. Therefore, to perform a consistent analysis of the medical supply industry, SIC 3693 (X-Ray, Electromedical, and Electrotherapeutic Apparatus) is used instead of SIC 3844 and SIC 3845 for the period before 1987. After 1987 , SIC 3693 was divided into SIC 3844 and SIC 3845. SIC 3693 ceased to exist. 
Table 3.1

Definition of the Medical Supply Industry

\begin{tabular}{|c|c|}
\hline IC & Definition \\
\hline & $\begin{array}{l}\text { Manufacturing medical, surgical, ophthalmic, \& } \\
\text { veterinary instruments \& apparatus. }\end{array}$ \\
\hline 42 & $\begin{array}{l}\text { Manufacturing orthopedic, prosthetic, and } \\
\text { surgical appliances \& supplies, arch supports } \\
\text { \& other foot appliances, fracture appliances, } \\
\text { elastic hosiery, abdominal supporters, braces, } \\
\text { \& trusses, bandages; surgical gauze \& } \\
\text { dressings, sutures; adhesive tapes \& medicated } \\
\text { plasters; \& personal safety appliances \& } \\
\text { equipments. }\end{array}$ \\
\hline$\Delta$ & $\begin{array}{l}\text { Manufacturing artificial teeth, dental metals, } \\
\text { alloys, \& amalgam, \& a wide variety of } \\
\text { equipment, instruments, \& supplies used by } \\
\text { dentists, dental laboratories and dental } \\
\text { colleges. }\end{array}$ \\
\hline 4 & $\begin{array}{l}\text { Manufacturing radiographic X-ray, fluoroscopic } \\
\text { x-ray, \& therapeutic X-ray apparatus \& tubes } \\
\text { for medical, industrial, research, \& control } \\
\text { applications, or in manufacturing other } \\
\text { irradiation equipment including gamma \& beta } \\
\text { ray equipment. }\end{array}$ \\
\hline & $\begin{array}{l}\text { Manufacturing electro-medical } \\
\text { therapeutic apparatus. }\end{array}$ \\
\hline
\end{tabular}

Source: US Office of Management \& Budget (1987:250-252). 


\subsubsection{Technology}

The development of the medical instrument and supply industry has been enhanced historically by the development of technology. As stated by Malecki:

"The development of instruments for chemical analysis of blood pressure and urine was fairly well advanced by the 1800s. But it was not until the 1950s that laboratory tests became automated, prompting a vast expansion of diagnostic testing." (1985:353)

During the same period, machines for continuously monitoring body functions such as blood pressure were being developed (Malecki, 1985:353). This industry has been affected by the recent development of ultrasonic equipment, hemodialysis apparatus, utilization of plastic products, and inhalation therapy equipment. High-tech products, including premixed drug solutions, continuous ambulatory peritoneal dialysis (CAPD), enteral nutritional feeding systems, cardiac angioplasty, and similar devices, also spurred the growth of medical supply industry (S\&P, 1991:H36). State-of-the-art high-tech products, such as magnetic resonance imaging (MRI) equipment, magnetic source imaging (MSI), digital medicalpicture arching and communications systems (PACS), ventricular-assist devices (VADs) and implantable defibrillators are expected to greatly strengthen the industry in the near future (S\&P, 1991:H37-H39). The enhancement of medical technology will continue to strive for safer products which are both medically and cost effective. 


\subsubsection{Government Regulations}

Government regulations have always played a significant role in the medical instruments and supply industry because of the industry's unique features. The effects of these regulations are two-fold. First, these regulations were generally introduced to require manufacturers of medical devices to produce safer, more medically effective, and cost effective products. To fulfill the requirements of these regulations, manufacturers of medical devices and suppliers have to increase the cost of developing and marketing new products. Second, it lengthens the time required for the introduction of new products. During the late 1970 s and 1980s, three pieces of government regulation created a profound impact on the medical supply industry and will continue to impact it in the foreseeable future. They are the Prospective Payment system (PPS), the Safe Medical Device Act (SMDA) and Good Manufacturing Practice for Medical Devices (GMP).

In response to the explosive growth of medical expenditures, the Federal government, in 1983, introduced the Prospective Payment system (PPS) which establishes cost ceilings for Medicare and Medicaid inpatient treatment (USDC, 1990:51-1). In other words, it reimburses hospitals for Medicare and Medicaid patients at pre-set rates. As a result of this cost-containment mechanism, hospitals have to curtail their costs through centralized and standardized purchasing, competitive bidding, and the formation of group purchasing 
organizations (USDC, 1986b:34-1). These have created intense pricing pressures on medical device suppliers. In view of these facts, the medical supply industry has responded by developing products that shorten the length of stay through better diagnostic methods and treatment procedures. Also, the industry invests in creating products that improve labor productivity or reduce labor costs. Moreover, the industry has responded by carefully looking at new and rapidly growing markets not covered by PPS such as freestanding ambulatory care centers, outpatient diagnostic centers, and home healthcare agencies (USDC, 1986b:34-1).

Initiated by Representatives Henry Waxman (D-Calif.) and John Dingell (D-Mich.) in 1989, the Safe Medical Device Act (SMDA) was passed by Congress and signed into law by President Bush in late 1990 (S\&P, 1991:H35). The SMDA requires higher standards of safety for medical devices. This new legislation is intended to replace the old $510(\mathrm{k})$ approval system (the 1976 Medical Device Amendment) with a more stringent product pre-marketing approval (PPA) process.

Under the old $510(k)$ approval system, only manufacturers were held responsible for reporting serious injuries or deaths from the operations of their products, whereas under the new law, these reports are also required from hospitals, clinics, and other end users (S\&P, 1991:H35). Moreover, this new bill requires user facilities to report deaths, serious injuries, 
or illnesses associated with such devices to the FDA and/or to the manufacturer within 10 days of occurrence.

Ninety percent of all medical devices that are presently cleared for sale under $510(\mathrm{k})$ system, are approved within 90 days. Under the new legislation, this review and approval system could take more than a year. Moreover, this new law requires post-market surveillance by any manufacturer of new implantable products whose malfunctioning could cause serious health problems.

SMDA will also impact the imposition of time limitations on patent rights for new medical devices. For example, SMDA provides that one year after the approval of four similar devices, the FDA may use the data in one producer's product pre-market approval for other purposes, including background information to grant approval for a competitor's product (S\&P, $1991:$ H36) .

The medical supply industry has opposed this new bill, claiming that the more complex and time consuming review system would retard the pace of new product innovation and lead to higher costs of medical equipment (S\&P, 1990:H33). This has also led to the rise of the industry's investment in R\&D to develop advanced and cost-effective products for the market (S\&P, 1990, 1991).

The good manufacturing practice for medical devices (GMP) was introduced in 1978 by the Federal government. It is intended to assure that medical devices will be safe and 
effective for human use. The regulation set forth the requirement for the production of medical devices in the different periods of the production process, from manufacturing, packing, storage and the final installation of all devices. The main purpose of the regulation is to control quality. It stipulates every finished medical device manufacturer should prepare and implement a quality assurance program in its production process.

The impact of this regulation on the medical supply industry are basically two-fold. First, it creates a special relationship between suppliers and manufacturers. On the one hand, suppliers have to meet strict requirements for manufacturers' acceptance of their products. On the other hand, once suppliers have fulfilled manufacturers' requirements, they become relatively advantaged in staying the market since other competitors have to meet the requirements first. In other words, these "approved" suppliers are in a relative safe position. This may lead to the continued successful performances of some small and medium suppliers while others fall by the wayside.

Secondly, it helps firms in the medical supply industry build their reputations. Once production is implemented through GMP, a certain level of quality is assumed. This helps manufacturers stay in and further penetrate both domestic and international markets. 


\subsubsection{Foreign Trade and Foreign Competition}

Foreign trade has always played a very important role in the medical supply industry. Table 3.2 contains data on exports and imports in the industry for the years 1972 through 1990. During this period, the medical supply industry's exports have always exceeded its imports. This has resulted an increase of trade surplus from $\$ 210 \mathrm{million}$ to $\$ 2,109 \mathrm{million}$, representing an average growth rate of $13.67 \%$. According to the estimate of the US Department of Commerce, exports in the medical supply industry are expected to rise $12 \%$ to $\$ 6.5$ billion in 1991. With imports expected to increase 9.1\%, to \$3.6 billion, the trade surplus would amount to about $\$ 2.9$ billion in 1991 (USDC, 1991a:H36).

The fact that the medical supply industry has performed extremely well in foreign trade is attributable to the following factors. First, the US is recognized as the global leader in the production of medical instrument and supplies due to its continuous development of new and sophisticated equipment. Second, foreign governments are increasing emphasis on providing quality health care services, and third, the lower value of the US dollar compared to most major world currencies has made US products cost-competitive.

However, the strengthening of the dollar combined with intensified competition from Japanese and German manufacturers, especially in big-ticket electromedical products, is expected to result in reduced trade surplus 
Table 3.2

Trade Deta for the Modical Supply Induxery 1972-1990 (in millions of dottens)

\begin{tabular}{|c|c|c|c|c|c|c|c|c|c|c|c|c|c|c|c|c|c|c|c|}
\hline SIC 3693 & 1972 & 1973 & 1974 & 1975 & 1976 & 197 & 1978 & 1970 & 190 & का & 192 & 193 & कि4 & 1965 & 196 & 197 & 108 & 1969 & 1900 \\
\hline Value of Exports & 81.2 & 107 & 152 & 196 & 223 & 328 & 5.99 & 717 & 837 & 1050 & 1025 & 1006 & 1009 & 1200 & 1350 & . & . & . & . \\
\hline Value of Imports & 662 & 92.1 & 121 & 173 & 199 & 235 & 239 & 275 & 312 & 380 & 487 & 673 & 840 & 910 & 1014 & - & - & . & . \\
\hline $\begin{array}{l}\text { Expors-Imports } \\
\text { SIC 3BA1 }\end{array}$ & 15 & 14.9 & " & 2.3 & 24 & 103 & 300 & 442 & 525 & 670 & 538 & 413 & 259 & 290 & 336 & - & . & - & . \\
\hline Value of Exports & 141 & 180 & 248 & 299 & 3.60 & 401 & .65 & 410 & 485 & 570 & $\cos$ & 579 & 618 & 62 & 74 & 765 & 963 & 1455 & 1601 \\
\hline Value of Imporas & 31.1 & 47.2 & 6.3 & 76.5 & ons & 92 & 126 & 146 & 174 & $20 x$ & 222 & 258 & 337 & 395 & 450 & 676 & $m 2$ & 626 & 620 \\
\hline $\begin{array}{l}\text { Exports-Imports } \\
\text { SIC 384? }\end{array}$ & 109.9 & 1328 & 185 & 222.5 & 273.5 & 300 & 239 & 264 & 311 & 365 & 383 & 321 & 281 & 267 & 294 & 89 & 171 & 829 & 931 \\
\hline Value of Expons & 76.6 & 83.2 & 117 & 133 & 159 & 178 & 226 & 258 & 309 & 345 & 375 & 402 & 142 & 491 & 560 & 521 & 68 & 906 & 1042 \\
\hline Value of Imports & 13.1 & 17.2 & 229 & 299 & 40.2 & 59 & 89 & 105 & 94 & 95 & 108 & 109 & 141 & 151 & 159 & 338 & 373 & 400 & 420 \\
\hline $\begin{array}{l}\text { Expors-Imports } \\
\text { SIC } 384,3\end{array}$ & 63.5 & 106 & 90.1 & 103.1 & 118.8 & 119 & 1.37 & 153 & 215 & 270 & 267 & 29.3 & 301 & .340 & 401 & 183 & 295 & .506 & 622 \\
\hline Value of Fxports & 34.3 & 48.5 & 72.4 & 82.1 & 84.5 & 92 & 79 & 101 & 127 & 140 & 143 & 146 & 137 & 144 & 154 & 272 & 322 & $2 n$ & 307 \\
\hline Value of Imports & 127 & 16.5 & 20.3 & 20.3 & 2.3 & 30 & 45 & 42 & +1 & so & 49.9 & $5 \$ 4$ & $\infty .3$ & 74.1 & 79.9 & IN & 112 & 1.31 & 143 \\
\hline $\begin{array}{l}\text { Exponts-Imports } \\
\text { SIC .3P44 }\end{array}$ & 21.6 & 32 & 52.1 & 61.8 & 61.5 & 62 & 34 & 59 & 86 & 90 & 93.1 & 90.6 & 20.7 & 69.9 & 74.1 & 168 & 210 & 146 & 164 \\
\hline Value of Fepponts & - & - & - & - & - & - & . & . & - & . & . & . & . & . & . & 338 & 410 & 466 & 508 \\
\hline Value of Imports & . & . & - & . & . & . & . & . & . & . & - & . & . & - & . & 76.3 & 860 & 795 & 866 \\
\hline $\begin{array}{l}\text { Exports-Imports } \\
\text { SIC } 3845\end{array}$ & - & - & - & - & - & - & - & - & - & - & - & - & - & - & - & .425 & -4.50 & -329 & -358 \\
\hline Value of Exports & - & - & - & . & - & . & - & - & - & . & . & - & . & - & . & 1274 & 1682 & 1549 & 1671 \\
\hline Vallue of Imports & - & . & . & . & . & . & . & - & . & . & . & . & . & . & . & 676 & 878 & 837 & 921 \\
\hline Exports-Imports & - & - & - & . & - & . & - & - & - & - & - & . & - & - & . & 598 & 804 & 712 & 750 \\
\hline Total & & & & & & & & & & & & & & & & & & & \\
\hline Value of Expmorts & 333.1 & 418.7 & \$R9.4 & 7101 & 826.5 & 1000 & 1200 & 1486 & 1758 & 2125 & 2148 & 2213 & $22 \%$ & 2497 & 2808 & ISSR & 1953 & 2628 & 2950 \\
\hline Value of Imports & 123.1 & 173 & 227.2 & 2007 & .48 .7 & $41 \mathrm{~h}$ & 490 & 568 & $6 ! 1$ & 730 & 8669 & 1005.4 & 1384.3 & 1530.1 & 1202.9 & 1118 & $12 n$ & 1157 & 1233 \\
\hline Expors-Imports & 210 & 245.7 & 3.622 & 910.4 & 477.8 & 59.3 & 710 & 918 & 1137 & 1395 & 1281.1 & 1117.6 & 911.7 & 969 & 1105.1 & 440 & 676 & 1481 & 1717 \\
\hline
\end{tabular}


growth in the years ahead (USDC, 1991a:H36). Moreover, Japan holds a considerable lead in the development of superconductivity, high definition television, and $x-r a y$ lithography. All of these areas will have an important bearing on the development of high-tech medical products, which will influence the performance of trade in the years ahead.

Another growing concern is the European community (EC) and its efforts to create a single internal market. While this new system may result in streamlined regulatory procedures and simplified marketing, it is also likely to encourage greater price competition (USDC, 1990:H33).

Medical suppliers are also interested in Eastern Europe and the former Soviet Union (now CIS) due to their recent vast political changes. Although new markets in these countries seems to be appearing, competition from the former soviet Union may occur if its sophisticated national defense system can be successfully transferred to civil usage.

\section{2 .4 other Factors}

Other factors like demography, litigation, newly diagnosed diseases such as AIDS and other infectious disease have also influenced development of the industry. The aging population of the US and other major trading partners (such as Japan and Western Europe) is stimulating the demand for quality medical products. According to the U.S. Census, the 65-and-over age cohort accounted for about $12.6 \%$ of the population in 1990, versus $11.2 \%$ in 1980. Estimates from the 
Bureau of Census are that this segment of the population will rise to $21 \%$ of the nation's population by the year 2030 (USDC, 1987b: H31).

Litigation is also contributing to the growth of the industry, as doctors and other medical professional often use costly diagnostic tests to protect themselves from devastating malpractice claims (USDC, 1991a:H35). The incidence of AIDS and other infectious disease has also resulted in increased demand for new diagnostic tests and other safeguards against these diseases.

\subsection{Value Added, Value of Shipments and Employment in the Industry}

The medical supply industry outpaced manufacturing as a whole in value added, employment, and value of shipments between 1963 and 1989, according to statistical records. Tables 3.3 and 3.4 reveal the historical development of the industry with regards to these three indicators. Value added grew from $\$ 721.3$ million in 1963 to $\$ 17,622.9$ million in 1989 , which makes up an annual average growth rate (AAGR) of $13.08 \%$ that far outpaced the $7.66 \%$ AAGR of the manufacturing sector during the same period of time. The medical instrument and supply industry's share in manufacturing value added increased from $0.38 \%$ to $1.35 \%$ within the same time span.

Employment increased from 57.6 thousand in 1963 to 222.4 thousand in 1989, with an annual average growth rate of $5.33 \%$. Again, this exceeds the manufacturing sectors AAGR of $0.45 \%$. 
Table 3.3

The Medical Supply Industry in Manufacturing by Value Added, Employment \& Value of Shipments (1963-1989)

\begin{tabular}{|c|c|c|c|c|c|c|c|c|c|}
\hline \multirow[b]{2}{*}{ Year } & \multicolumn{3}{|c|}{ Value Added in Billions } & \multicolumn{3}{|c|}{ Emploment in Millions } & \multicolumn{3}{|c|}{ Value of Shipments in Millions } \\
\hline & Medi. & Manu. & $\begin{array}{l}\text { \% of Medi. } \\
\text { in Manu. }\end{array}$ & Medi. & Manu. & $\begin{array}{l}\text { \% of Medi. } \\
\text { in Manu. }\end{array}$ & Medi. & Manu. & $\begin{array}{l}\text { \%o of Medi. } \\
\text { in Manu. }\end{array}$ \\
\hline 1963 & 0.72 & 192 & 0.38 & 0.06 & 17.00 & 0.34 & 1172.2 & 420528.1 & 0.28 \\
\hline 1964 & 0.74 & 206 & 0.36 & 0.06 & 17.30 & 0.33 & 1233.0 & 447985.1 & 0.28 \\
\hline 1965 & 0.83 & 227 & 0.37 & 0.06 & 18.00 & 0.35 & 1336.4 & 492005.7 & 0.27 \\
\hline 1966 & 0.96 & 251 & 0.38 & 0.07 & 19.10 & 0.37 & 1557.0 & 538736.9 & 0.29 \\
\hline 1967 & 1.10 & 262 & 0.42 & 0.08 & 19.30 & 0.39 & 1767.0 & 557397.8 & 0.32 \\
\hline 1968 & 1.31 & 285 & 0.46 & 0.08 & 19.60 & 0.42 & 2078.8 & 603220.1 & 0.34 \\
\hline 1969 & 1.48 & 306 & 0.48 & 0.09 & 20.00 & 0.45 & 2348.6 & 642635.8 & 0.37 \\
\hline 1970 & 1.48 & 300 & 0.49 & 0.09 & 19.20 & 0.45 & 2339.8 & 6343221 & 0.37 \\
\hline 1971 & 1.74 & 314 & 0.55 & 0.09 & 18.40 & 0.48 & 2651.7 & 670970.5 & 0.40 \\
\hline 1972 & 2.13 & 354 & 0.60 & 0.10 & 19.00 & 0.54 & 3268.2 & 756534.3 & 0.43 \\
\hline 1973 & 2.35 & 404 & 0.58 & 0.11 & 19.90 & 0.54 & 3638.1 & 875443.2 & 0.42 \\
\hline 1974 & 2.75 & 452 & 0.61 & 0.12 & 19.80 & 0.61 & 4449.4 & 1017873.4 & 0.44 \\
\hline 1975 & 3.14 & 442 & 0.71 & 0.13 & 18.30 & 0.69 & 5114.9 & 1039377.4 & 0.49 \\
\hline 1976 & 3.47 & 511 & 0.68 & 0.13 & 18.80 & 0.69 & 5712.6 & 1185695.3 & 0.48 \\
\hline 1977 & 4.49 & 585 & 0.77 & 0.14 & 19.60 & 0.73 & 7089.0 & 1358526.4 & 0.52 \\
\hline 1978 & 4.95 & 657 & 0.75 & 0.16 & 20.50 & 0.76 & 7940.0 & 1522937.3 & 0.52 \\
\hline 1979 & 5.66 & 747 & 0.76 & 0.16 & 21.00 & 0.76 & 9124.7 & 1727214.6 & 0.53 \\
\hline 1980 & 6.28 & 774 & 0.81 & 0.17 & 20.60 & 0.82 & 10338.1 & 1852668.3 & 0.56 \\
\hline 1981 & 7.64 & 838 & 0.91 & 0.18 & 20.30 & 0.88 & 12409.0 & 2017542.5 & 0.62 \\
\hline 1982 & 9.71 & 824 & 1.18 & 0.19 & 19.10 & 0.99 & 15133.3 & 19602058 & 0.77 \\
\hline 1983 & 10.23 & 882 & 1.16 & 0.19 & 18.70 & 1.01 & 16069.9 & 2045853.3 & 0.79 \\
\hline 1984 & 11.70 & 984 & 1.19 & 0.20 & 19.10 & 1.03 & 18135.0 & 2253429.3 & 0.80 \\
\hline 1985 & 12.50 & 1000 & 1.25 & 0.20 & 18.80 & 1.06 & 19205.9 & 2280183.8 & 0.84 \\
\hline 1986 & 12.82 & 1035 & 1.24 & 0.20 & 18.40 & 1.08 & 19621.7 & 2260314.5 & 0.87 \\
\hline 1987 & 14.73 & 1167 & 1.26 & 0.20 & 18.90 & 1.08 & 22838.7 & 2475901.0 & 0.92 \\
\hline 1988 & 16.88 & 1262 & 1.34 & 0.21 & 19.15 & 1.10 & 25329.8 & 2682605.9 & 0.94 \\
\hline 1989 & 17.62 & 1308 & 1.35 & 0.22 & 19.04 & 1.16 & 27183.0 & 2793014.5 & 0.97 \\
\hline
\end{tabular}

Source: Calculated from the Census of Manufactures, 1977, 1982 and 1987; and The Annual Surrey of Manufactures, 1984,1986 and 1989. US Depu. of Commerce, Bureau of Census. 
Table 3.4

Comparison of the Medical Supply Industry and Manufacturing by Annual Average Growth Rate (1963-1989) in Percent

\begin{tabular}{lccc}
\hline & Value Added & Employment & Value of Shipments \\
\hline Manu. & 7.66 & 0.45 & 7.55 \\
Medical & 13.08 & 5.33 & 12.85 \\
\hline
\end{tabular}

Source: Calculated from The Census of Manufactures, 1972, 1977, 1982, and 1987 and The Annual Survey of Manufactures, 1984, 1986 and 1989. US Dept. of Commerce, Bureau of Census. 
The share of manufacturing employment has also increased from 0.348 in 1963 to $1.16 \%$ in 1989.

The industry's value of shipments grew from $\$ 1,172,2$ million in 1963 to $\$ 27,183$ million in 1989 . It has resulted in an annual average growth rate of $12.85 \%$. This rate surpassed the overall manufacturing growth rate of $7.55 \%$. The share in total manufacturing value of shipments also increased from $0.28 \%$ to $0.97 \%$.

The medical supply industry's pace of development is also evident in comparison with other instrument-related industries. Table 3.5 summarizes the comparison. The medical supply industry (SIC384) increased its share in SIC 38 (instruments and related products) value added from $16.84 \%$ in 1970 to $22.44 \%$ in 1989 . Its position in all industries within SIC 38 has constantly remained in third place during the past three decades. With regard to employment, the medical supply industry boosted its share in SIC 38 from $19.17 \%$ in 1970 to $22.99 \%$ in 1989, and has maintained its position in third place. Value of shipments, another indicator, also shows that the medical supply industry has grown at a considerable rate. Proportionally, SIC 38 increased from $18.75 \%$ in 1970 to $25.85 \%$ in 1989. Its ranking amongst all industries in SIC 38 slightly decreased from second to third place.

In conclusion, the medical supply industry has undergone substantial growth during the last three decades. Its importance in manufacturing has also gradually increased. 
Table 3.5

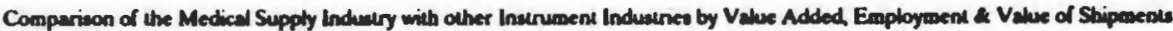

\begin{tabular}{|c|c|c|c|c|c|c|c|c|c|c|c|c|}
\hline \multirow{3}{*}{$\begin{array}{l}\text { Value Added in Million Dollars } \\
\text { InduestrySIC Code }\end{array}$} & \multirow[b]{3}{*}{1920} & \multirow[b]{3}{*}{1980} & \multirow[b]{3}{*}{1985} & \multirow[b]{3}{*}{1989} & \multirow{3}{*}{$\begin{array}{l}\text { \%o d } \\
\text { lotal } \\
1970\end{array}$} & \multirow{3}{*}{$\begin{array}{l}\text { \%o } \\
1001 \\
1970\end{array}$} & \multirow{3}{*}{$\begin{array}{l}\text { Tof } \\
\text { lotal } \\
1970\end{array}$} & \multirow{3}{*}{$\begin{array}{l}\text { Tof } \\
\text { cotal } \\
1970\end{array}$} & \multicolumn{3}{|c|}{ Rant } & \multirow[b]{3}{*}{1939} \\
\hline & & & & & & & & & & & & \\
\hline & & & & & & & & & 1920 & 1820 & 1983 & \\
\hline Tat SIC 38 & 7905.3 & 21913.1 & $\$ 0278.3$ & 785468 & 100.00 & 10000 & 10000 & 10000 & & & & \\
\hline Phowograptic Equipment \& Suppliea (386) & 3187.3 & 9930.8 & 12257.4 & 15804.2 & 40.32 & 45.32 & 30.43 & 20.12 & 1 & 1 & 1 & 4 \\
\hline Memaring \& Conyrollthng Devioes (382) & 1535.0 & 8127.8 & 11621.6 & 1724.8 & 19.42 & 37.09 & 28.85 & 22.64 & 2 & 2 & 2 & 2 \\
\hline Medical Supply Indusiry (381) & 1331.6 & 4090.8 & 9243.8 & 17623.0 & 16.84 & 21.41 & 22.95 & 22.44 & 3 & 3 & 3 & 3 \\
\hline Searct \& Navigalion Equipenent (381) & 725.3 & 1821.3 & 2581.0 & 23924.5 & 9.17 & 8.31 & 6.41 & 30.46 & 4 & $\mathbf{s}$ & $\mathbf{s}$ & 1 \\
\hline Walcher, Clocks, \& Walchcaves (307) & +69.0 & 603.5 & 418.6 & 081.4 & 5.93 & 3.03 & 1.04 & 0.87 & 5 & 7 & 7 & 7 \\
\hline Ophuhalmac Goodh (385) & 359.7 & 839.0 & 995.6 & 1542.6 & 4.55 & 3.83 & 2.47 & 1.96 & 6 & 6 & 6 & 5 \\
\hline Optical lastruments \& Lensess (383) & 297.4 & 1839.8 & 31603 & 11843 & 3.76 & 8.40 & 7.85 & 1.51 & 7 & 4 & 4 & 6 \\
\hline & & & & & ad & $\% 0$ & कo & \%o & Rank & Rank & Rank & Rank \\
\hline Employments in Thoueands & & & & & Iotial & lotid & tolat & Iotal & n & $n$ & in & in \\
\hline Induatry/SIC Code & 1920 & 1930 & 1985 & 1989 & 1970 & 1970 & 1970 & 1970 & 1970 & 1980 & 1935 & 1989 \\
\hline Toul sic38 & 904.6 & 6164 & 604.3 & 967.5 & 10000 & 10000 & 10000 & 10000 & & & & \\
\hline Measuring \& Conurollung Devives (382) & 10.1 .8 & 231.8 & 217.1 & 2620 & 25.05 & 37.61 & 35.93 & 27.08 & 1 & 1 & 1 & 2 \\
\hline |'thurographic Equppmen1 \& Supples (386) & 92.5 & 114.2 & w.s & 87.0 & 22.86 & 18.53 & 16.30 & 8.99 & 2 & 3 & 3 & 4 \\
\hline Medical Suppty Induaury (384) & 77.0 & 129.8 & 152.1 & 222.4 & 19.17 & 21.00 & 25.17 & 22.99 & 3 & 2 & 2 & 3 \\
\hline Search \& Nawyzion Equiponent (381) & 50.5 & 44.7 & 467 & 339.5 & 12.48 & 7.25 & 7.73 & 35.04 & 4 & 1 & $\mathbf{s}$ & 1 \\
\hline Wadcter, Clortes, and Warchcomes (387) & 35.0 & 23.0 & 11.8 & 10.5 & 8.05 & 3.73 & 1.95 & 1.04 & s & 7 & 7 & 7 \\
\hline Ophithalmic Gooda (.385) & 27.1 & 29.4 & 24.9 & 25.0 & $6 \%$ & 4.77 & 4.12 & 2.58 & 6 & - & - & 5 \\
\hline \multirow[t]{2}{*}{ Opticil Inouruments \& Lenars (383) } & 18.2 & 43.5 & 53.2 & 21.1 & 4.50 & 7.06 & 8.80 & 2.18 & 7 & 5 & 4 & 6 \\
\hline & & & & & \%.d & कof & $x$ of & कof & Rent & $\operatorname{Ren}$ & Rent & Rent \\
\hline Value of Shipments in Mullion Dollars & & & & & Ioxal & toral & total & total & m & in & m & in \\
\hline Indusarysic Code & 1970 & 190 & 1485 & 1989 & 1970 & 1970 & 1920 & 1970 & 1970 & 1980 & 1983 & 1989 \\
\hline Tow SIC38 & 117825 & 44138.7 & 61000.2 & 118486.1 & 10000 & 10000 & 10000 & 10000 & & & & \\
\hline Phorographic Equipment \& Supplues (386) & 4413.5 & 15867.0 & 18114.4 & 22737.8 & 37.46 & 35.95 & 29.69 & 19.19 & 1 & 1 & 1 & 4 \\
\hline Measuring \& Controlling Devices (382) & 2261.9 & 12327.1 & 17479.9 & 27710.8 & 19.20 & 27.93 & 28.05 & 23.39 & 2 & 2 & 2 & 2 \\
\hline Medeal Supply Induarery (384) & 2087.0 & 7809.4 & 14202.8 & 27183.0 & 17.71 & 17.09 & 23.28 & 22.94 & 3 & 3 & 3 & 3 \\
\hline Search \& Navigation Equipment (381) & 1180.6 & 2067.6 & 3933.9 & .35295 .4 & 10.02 & 6.04 & 6.45 & 29.79 & 4 & s & $\mathbf{s}$ & 1 \\
\hline Walcher, Clocks, and Walchicases (387) & 888.8 & 1511.6 & 912.1 & 1448.0 & 7.54 & 3.42 & 1.50 & 1.22 & s & - & 6 & 7 \\
\hline Ophithalmic Goods (385) & 518.8 & 1211.9 & 1418.2 & 2193.5 & 4.40 & 2.75 & 2.32 & 1.85 & 6 & 7 & 7 & 5 \\
\hline Optical Ineuruments \& Lenees (383) & 431.9 & 2744.0 & 4946.9 & 1917.5 & 3.67 & 6.22 & 8.11 & 1.62 & 2 & 4 & 4 & 6 \\
\hline
\end{tabular}

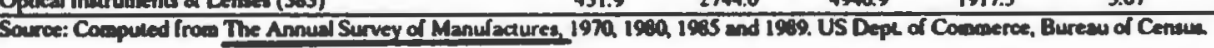


Compared with other instrument and supply industries, the medical supply industry performed very well. It has continuously outperformed other segments of the instrument industry and has maintained a strong, stable and higher ranking record compared to all instrument-related industries. 


\section{Chapter Four \\ The Medical Supply Industry Today}

This chapter examines the current profile of the industry. It starts by looking at the industry's composition, followed by a discussion of the distribution of firms by size. Then, the focus shifts to the spatial distribution of the industry. Finally, brief descriptions of some leading companies in the industry are presented.

\subsection{The Industry Composition}

Table 4.1 summarizes the industry's composition. Surgical appliances and supplies (SIC 3842), the industry's broadest and most diverse group, ranks first in its value added, employment and value of shipments. Surgical and medical instruments (SIC 3841) ranks second. These two industries together comprise more than $70 \%$ of the industry's shipments and employment. In other words, the medical supply industry is dominated mainly by surgical appliances and supplies (SIC 3842) and surgical and medical instruments (SIC 3841).

The industry is extremely diverse with regards to products. It includes more than three thousand companies producing more than 130,000 different products (S\&P, 1987:H30), ranging from basic gauze pads to complicated magnetic resonance imaging (MRI) equipment. The eight largest companies in the industry account for about two-fifths of industry shipments (S\&P, 1987:H30). 


\section{Table 4.1}

Composition of the Medical Supply Industry by Value Added, Employment and Value of Shipments

\begin{tabular}{lrrrrrr}
\hline SIC CODE & \multicolumn{2}{l}{$\begin{array}{l}\text { Value Added \% of } \\
\text { million \$ }\end{array}$} & $\begin{array}{l}\text { Employmen \% of } \\
\text { total }\end{array}$ & $\begin{array}{l}\text { Value of Ship- } \\
\text { thousands }\end{array}$ & $\begin{array}{r}\text { \% of } \\
\text { total } \\
\text { ment million \$ }\end{array}$ & \begin{tabular}{l} 
total \\
\hline 3841
\end{tabular} \\
3842 & $6,059.8$ & 34.4 & 83.9 & 37.7 & $8,971.6$ & 33.0 \\
3843 & $6,504.4$ & 36.9 & 84.4 & 37.9 & $10,187.1$ & 37.5 \\
3844 & 851.9 & 4.8 & 12.9 & 5.8 & $1,277.1$ & 4.7 \\
3845 & $1,113.6$ & 6.3 & 9.4 & 4.2 & $1,925.8$ & 7.1 \\
& $3,093.2$ & 17.6 & 31.8 & 14.3 & $4,821.4$ & 17.7 \\
Total & $17,622.9$ & 100.0 & 222.4 & 100.0 & $27,183.0$ & 100.0 \\
& & & & & &
\end{tabular}

Source: Computed from The Annual Survey of Manufactures, 1989 US Dept. of Commerce, Bureau of Census. 
line of human health care products and services. These are divided into two groups: (1) pharmaceutical and nutritional products and (2) hospital and laboratory products.

Pharmaceutical and nutritional products include adult and pediatric pharmaceuticals, nutritionals, and vitamins, which are sold primarily by prescription or the recommendation of physicians or other health care professionals. It comprised $51.3 \%$ of 1990 company's sales (S\&P, 1991:H37). It also includes personal care products, agricultural and chemical products, and bulk pharmaceuticals.

Abbot's hospital and laboratory products include diagnostic systems for blood banks, hospital and clinical laboratories, and alternate care testing sites; intravenous and irrigating fluids and related administration equipment; venipuncture products; anesthetics, critical care equipment; and other specialty products for hospitals, clinical laboratories, and alternate care sites. It accounted for $48.7 \%$ of the company's sales in 1990 (S\%P, 1991:H37).

\subsubsection{Baxter International Inc.}

This company was originally incorporated in 1931 as Baxter Laboratories Incorporated. It was renamed Baxter Travenol Laboratories Inc. in 1976 and adopted its present name in 1987 . In 1989 , it ranked third in the industry with $\$ 446$ million net income (S\&P, 1990:H46). By 1990 it had 64,600 employees. Eighty two point twenty seven percent of its total 
sales and $49.17 \%$ of its operating income came from US operations.

The company is engaged in the worldwide development, manufacture and distribution of a diversified line of products, systems and services used primarily in the health care field. It is further divided into four groups: hospital products and services, medical systems and specialties, alternate site products and services, and industrial products.

Hospital products and services include a broad range of products for hospitals and clinical laboratories, such as products for intravenous therapy, products for administering intravenous solutions, specialty labware, diagnostic and microbiological instrumentation, and reagent systems and supplies. Medical systems and specialties include a variety of specialized medical products used for patient care, blood therapy, diagnostic purposes and cardiac care.

Alternate site products and services include a broad range of supplies, equipment and services for home patients and alternate-site providers. Industrial products include products for educational and government laboratories, industrial research and development facilities and manufacturing facilities.

\subsubsection{Becton Dickinson \& Co.}

Originally incorporated in New Jersey in 1906, this company expanded to 18,500 employees and 6,854 stockholders by 
1990. In 1989, its net income ranked fourth (\$158 millions) among all establishments in the industry (S\&P, 1990:H46).

The company is engaged in two major health care segments: medical and diagnostic. Medical products include disposable and reusable hypodermic equipment, intravenous supplies, operating room products, cardiovascular devices, suction products, elastic support products, surgical blades, thermometers, examination gloves and contract packaging services. Medical products occupied $57.4 \%$ of the company's sales in 1990 (S\&P, 1991:H37). Diagnostic products include blood collection products, laboratory ware and supplies, manual and instrumented microbiology products, hematology instruments and other diagnostic systems, including immunodiagnostic test kits and instrumentation systems. Diagnostic products contributed the balance (42.6\%) of the company's sales (S\&P, 1991:H37).

\subsubsection{Bausch \& Lomb Inc.}

Incorporated in 1908 in New York, this company had expanded to 13,000 employees and 6,900 stockholders by 1990 . Its net income ranked fifth (\$114.4 millions) among all establishments of the industry in 1989 (S\&P, 1990:H46). The company develops, manufactures, and markets health care and optical products, with major product lines in the personal health, medical, biomedical and optics fields.

Health care products include personal health, medical and biomedical products. In the personal health area, major lines 
are: solutions for the care of contacts lenses and the relief of eye irritation, contact lens accessories, certain over-thecounter pharmaceutical products, home plaque removal devices and other oral care products. Medical products include contact lenses and lens materials, prescription pharmaceuticals, periodontal charting and exam systems, healing aids and healing diagnostic systems. Biomedical products include purpose-bred laboratory animals for biomedical research and a variety of biotechnical and professional services provided to the scientific research community. Optical products include sunglasses, ophthalmic frames, binoculars, rifle scopes, telescopes and optical thin film coatings. 


\section{Chapter Five}

\section{Flexibility in the Medical Instrument and supply Industry}

This chapter addresses the issue of "whether or not the industry is becoming more flexible and, if so, how?". The discussion starts by examining the strategies adopted in the industry in general when it is influenced by many different factors. Following that, the interviews conducted for this research are discussed. Third, some national characteristics of the medical supply industry are presented. Finally, in light of these primary and secondary data, the question of flexibility is addressed head-on.

\subsection{Strategies Adopted by the Industry in General}

During the past two decades or so, especially in the last 10 years, the medical supply industry has faced different challenges. As discussed in chapter 3, factors like changes in technology, intensive government regulation, foreign competition, and aging demography have played significant roles in the development of the medical supply industry. This section focuses on the industry's response to these changes, as well as the strategies it has adopted to cope with these challenges.

\subsubsection{Improving and Advancing Technology to Reduce Costs}

Under the influence of the 1983 Prospective Payment System (PPS), cost-saving has risen as an importance concern for the medical supply industry. PPS establishes cost ceilings 
for Medicare and Medicaid patients, resulting in hospitals and other buyers of medical devices and suppliers being pressured to hold down costs. The industry's strategies aim at improving and advancing technology to produce equipment that can reduce labor cost, increase labor productivity, reduce hospital stay of patients, or facilitate patient care in less expensive environments.

Early examples of these products include computerenhanced diagnostic imaging systems, sensory aids for handicapped persons, implanted prosthetic devices, patient monitoring systems, automated clinical analytical laboratory analysis units, and computer-based medical information systems (USDC, 1982b:277). Many of these products raise productivity in the delivery of health-care services thereby reducing the unit cost (USDC, 1982b).

Examples of recent products that have fostered efficiency include ultrasonic, radiologic, and magnetic resonance imaging devices that show clear pictures of internal organs in three dimensions; patient monitoring systems that, in seconds, provide physiological parameters of the critically ill; and devices that crush kidney stones (USDC, 1986b:34-1). These complex, technology-intensive, devices are relatively easy to use because of built-in features for operation, safety, selfcalibration, fault diagnosis, and repair. Hence, they increases labor productivity and reduces unit costs. 
The most up-to-date technological advances that have boosted efficiency include increased use of premixed drug solutions, which has reduced hospital pharmacy costs; continuous ambulatory peritoneal dialysis (CAPD), instead of the more costly in-hospital hemodialysis for patients with kidney failure; enteral nutritional feeding systems which have been substituted for in-patient parenteral (intravenous) feeding; lasers for ophthalmological, dermatological, and various other surgical applications; and cardiac angioplasty, which is a cost-effective alternative to bypass surgery for treating arteriosclerosis in coronary arteries (S\&P, 1986:H30, 1991:H36).

Another rapidly expanding market is laparoscopic, or endoscopic, surgical instruments. Laparoscopic surgery is accomplished by making a tiny hole through which to insert the laparoscope into a patient's body, instead of the six to eight inch incision necessitated by conventional surgical procedures. Because this procedure is less invasive and less traumatic to the patient, it typically involves much less pain and recovery time and results in substantial cost savings (S\&P, 1991:H37). Johnson \& Johnson recently launched a major campaign to move aggressively in the laparoscopic market. Through its Ethicon subsidiary, J\&J introduced a full line of disposable laparoscopic instruments and stated its commitment to become the market leader in this fast growing field (S\&P, 1991:H37) . 


\subsubsection{Penetrating into Drug Production}

Firms in the industry also moved into drug production, which is characterized by a growing market and relative lack of control from government. By aligning with traditional drug producers, the medical supply industry has initiated ambitious research and development programs, which have created successfully innovative, high-technology products. Traditional company, like $J \& J$ has expanded their presence in the pharmaceutical business in recent years and continue to invest heavily in new drug research and development (S\&P, 1991:H36) . In 1990, J\&J's sale of pharmaceuticals accounted for 33.18 of company sales (S\&P, 1991:H37) as compared to $21.2 \%$ in 1984 (S\&P, 1986:H29) .

The effort also extends to the international level. To cite one example, Baxter International and American Cyanamid formed a partnership with Quadra Logic Technologies of Vancouver, British Columbia to develop photodynamic drugs to help fight cancers (WSJ, 1990a).

\subsection{3 offering Long-Term Contracts to Maintain Market share}

Hospitals and other health-care providers have sought significant price discounts on medical products under the severe budgetary constraints imposed by PPS $^{4}$. Medical suppliers have offered long-term contracts at competitive prices with major buyers to lock up business. For example,

${ }^{4}$ In 1989, 52\% of sales of medical products in the Us were from hospitals, which are subject to PPS (S\&P, 1991:H35). 
Abbott Laboratories cut prices on intravenous (IV) equipment by about $30 \%$ in a major, five-year contract with the voluntary Hospitals of America to maintain market share in a shrinking business (S\&P, 1990:H35). Baxter International also reached a five-year supply and service agreement with Mercy National Purchasing Inc. The agreement mainly involves medical and surgical supplies and diagnostic equipment. Baxter's strategy is to seek a more comprehensive and closer supply and service relationship with buyers (WSJ, 1990b).

\subsubsection{Targeting Non-hospital Markets}

Under PPS, medical suppliers have responded by targeting non-hospital markets, such as independent physicians, home health-care agencies, and other providers of health careproviders, which are not covered by PPS. By increasing sales to these non-hospital markets, the industry has maintained steady growth.

\subsubsection{Targeting Geriatric Markets}

Facing the "Graying of America," as well as the fact that today's elderlys tend to be nearly twice as wealthy as the general population (S\&P, 1987:H31) and consume high amounts of medical products and services ${ }^{6}$, the industry has targeted new technological products to serve the geriatric market. These over.

${ }^{5}$ The Bureau of Census defines elderly as ages 65-and-

${ }^{6} \mathrm{About}$ two-thirds of all medical products and services in the U.S are consumed by elderly persons (S\&P, 1987:H32). 
include items such as intraocular lens implants, non-invasive kidney stone removal instruments, cardiac valve prostheses, artificial sphincters for urinary control, incontinence products and organ transplants (S\&P, 1987:H32).

\subsubsection{Exploring Foreign Markets}

Facing intensive regulation domestically, the industry has made efforts to explore international markets. Mechanisms include selling old patents to international firms, purchasing foreign companies, and undertaking intensive international marketing strategies. J\&J reported allowing England's largest patent manager, British Technology Group to market its patents overseas. This strategy of selling licenses for its medicalimaging technology products such as radiography, ultrasound, and computer tomography was an attempt to earn some extra revenue from old J\&J patents (WSJ, 1989). GE purchased a French diagnostic imaging equipment maker, Thomson-CGR, the medical equipment division of an electronic manufacturer, so that GE would have a stronger position in the European and Latin American market (WSJ, 1987). Bausch \& Laumb created an international division aimed at marketing its products (WSJ, 1990c). American Hospital Supply merged with Baxter Travenol in 1986 so that American Hospital Supply could have access to Baxter's huge international marketing system while Baxter could make use of America's extensive domestic distribution system ( $\& \& \mathrm{P}, 1986: \mathrm{H} 30)$. 


\subsection{Results of Industry Interviews}

To further understand the industry, representatives from five medical supply companies in New England were interviewed. Each company was asked questions about company history, location, the production process, and labor. To maintain confidentiality, company names are represented by the letters $A, B, C, D$, and $E$.

\section{2 .1 Company History}

Company A was founded by a British company in 1948. The present owner has owned it since 1960. It operated in Providence for 30 years and in Northern, RI its current location, for four years. The company basically manufactures custom needles, most of which are reusable. The current site is also its only manufacturing facility.

Company B was founded in a small town near Boston, MA, where it still operates, in 1932. It is a family-owned business, currently in its fourth generation of family management. The company produces mainly disposable and veterinary needles, but also produces different types of needles as required by customer orders.

Company $\mathrm{C}$ has been located in southeastern, MA since 1968, before it moved out from east Boston. The company manufactures products researched and developed by physicians.

Company D has been located in the same town as B since 1971. Its main products include osmometers and other testing instruments such as those used to test dairy products. 
Company $\mathrm{E}$ was started in the immediate Boston area 152 years ago. It was bought by a major international firm and moved to its current location, southeastern, MA, in 1965. The current site is basically for research, marketing and other administrative activities. The company's manufacturing activities are in an older industrial city also in southeastern, MA. The firm is one of the world leaders in the production of surgical instruments.

\section{2 .2 Location}

Although the current site has easy access to the airport, inter-state highway, and a good labor market, company A moved to its current location principally because of its new facility and improved building conditions. In other words, location was not a very critical factor in relocating this firm. The owner would have moved to any other place as long as a suitable building was available.

Company B's current location is an historical legacy since it was started as a family business at its current site and continues to operate there. The present manager mentioned that the site enjoys the advantages of inexpensive space and availability of labor.

Company $c$ has a different story regarding its location. It moved out from east Boston to its current site because of a rash of break-ins by drug addicts at the old location. It relocated to its current facility to avoid further break-ins and to take advantage of its proximity to Boston. However, 
since the state has taken away many incentives for businesses to operate here, the manager said the company would choose to go elsewhere if it were to relocate now.

Managers from Company D stated that, "location is largely irrelevant." While the company does enjoy the advantage of easy highway access for the employees, it need not be close to any suppliers or customers because of its small volume of shipments. All that is required is a place where there is UPS delivery and pick up and an easily accessible highway. However, managers mentioned that they would still locate here or within 10 miles of the current site since the highway system does provide convenience for employees to travel to and from work.

The choice of location for company $\mathrm{E}$ is a bit unique. The company has a site for non-manufacturing purposes and a site for manufacturing activities. The non-manufacturing site is located mainly for its proximity to Boston. The manufacturing site is located basically for its availability of labor force. still, the sites are only about 20 miles apart.

Most firms' managers told us location is largely irrelevant in their decision on where to locate because of the low volume of shipments. Reasons for current locations include historical legacies, new facilities, better building conditions, and avoiding break-ins. However, one thing the firms share in common is that the availability of good labor as a decisive factor in locating the company. Also, most firms 
benefit from proximity to Boston so that they can take advantage of medical R\&D in Boston.

\subsubsection{Production process}

Company A's only function is manufacturing. Other decisions regarding management, marketing, accounting, banking, and other services are basically handled by the parent company in Long Island. The company produces customer needles, mostly reusable needles, and veterinarian thermometers. The production process is very much standardized, involving only simple machines. Batch production is the principal form of production in this company. The company has done very little sub-contracting to other firms since the batches are too small to make subcontracts economical. The company cannot afford to buy hi-tech, sophisticated machines since these machines require larger quantities of output to justify their costs.

Company $B$ is also involved in the production of needles. The production process requires simple, functional, and sometimes old fashioned machines. It is a small batch/job shop type of production. The company claims its success as a niche player. The company also produces various types of needles as requested by customers using the same machines. Labor skills are more important than machines in producing custom orders. 
Company $c$ involves production of equipment developed by doctors'. It contains mass production of components and then assembly into specialized products. The company has received considerable assistance from a large medical supply company and has access to capital. The company has invested heavily in hi-tech machines, hoping that automation will enable it to "bump heads" with big firms and go into new markets. No subcontracting has been offered.

Company $D^{\prime}$ s production process is defined by the manager as "discontinuous batch processing." It mainly produces osmometers and testing devices for blood and dairy products. The whole production process is vertically integrated, involving basic technologies. However, the computer software and chemical tests are very much R\&D intensive.

Company $E$ is one of the world leaders in the production of surgical instruments. According to its chief engineer, its plant is as modern as any surgical instrument plant in the world and production is totally vertically integrated. The company has its own research, marketing and sales departments. It heavily invests in hi-tech so that it will maintain its leadership role in the world medical instrument markets. It uses numerically controlled machines, computerized numerically controlled machines, computer-aided design, production cells,

\footnotetext{
${ }^{7}$ We were not allowed to visit the workshop of the company, perhaps due to the company's concern over confidentiality of its products. All information was obtained through conversations with the CEO.
} 
statistical process control systems, robots, and automated material handling devices.

Although company $\mathbf{E}$ has made tremendous efforts to introduce new products and process innovations, three of five firms in our interviews still manufacture devices or equipment using old-fashioned methods. These firms still rely on simple and easy to operate machines, with new workers requiring little training. The firms are also characterized by the separation of management and production. Production workers are seldom involved in company policy. Most of the firms claim that they are vertically integrated and use batch production. In this sense, the whole process of production is done within that firm. Only a few firms have occasional sub-contracting when workloads are too high.

However, even these firms do achieve some measure of flexibility through the use of unsophisticated machines to produce different products. Many small firms use this strategy to achieve their success as a niche player in an increasingly competitive market.

\section{2 .4 Labor}

Company A currently employs about 50 full time and 2 part time workers (20 hours a week). However, the company prefers permanent workers and likes to hire individuals who want to make a career in this type of business. Therefore, ideal persons for them would be those in their late 20's to early 30 's, married and with children. It also wants new employees 
who fit into the group and do not disrupt its harmony. New employees usually need 90 probation days and six months to one year's training. The wage scales range from $\$ 6.5$ to $\$ 11$ per hour.

Company $A$ is not unionized. The manager believes that this is very important for the company. He feels a union would not allow the company to move workers around to different tasks. Since the company requires workers to understand manufacturing process from beginning to end, it is a common practice for the workers to be fully interchangeable in different aspects of production. However, the company does not use flexible hours. The company has a solid labor force and its turnover rate is very low, with some employees having worked there for 30 years.

Company B has about 30 employees. Most workers are older, retired people, with an average age of 64 . The training period for new employees is basically 1 to 2 weeks. However, no formal training is undertaken. The company's labor strategy is to use cheap ( $\$ 4.5$ to $\$ 8$ per hour), part time labor and to provide no health program for the employees so that it can reduce production costs and survive in its competitive environment. All employees are involved in production and quality control. The company allow great flexibility for workers to work from 15 to 35 hours per week.

Company C employs 54 people. All employees are full time and about 50\% are female. Training of new employees requires 
about one year with the company using manual and video assisting tools as part of the training process. One of the company's large client helped set up the training program. Wage scales are relatively high, ranging from $\$ 7.50$ to $\$ 18$ per hour. Production workers also do quality control. Some rotation of jobs does occur. The company also uses a system of productivity targets for workers. This system is basically based on historical experience with specific products. When business is good, the company allows workers to work overtime. Company D currently employs 74 people, all full time workers. Occasionally, the company hires some temporary workers. Wage scales are very competitive, ranging from $\$ 10$ to $\$ 15$ per hour. The company requires no formal training for new employees. However, on-the-job training takes about 6 months. All workers must understand all procedures of production and be aware of quality control. The company also rotates the production workers between tasks so that every worker can do different tasks when necessary.

Company $\mathrm{E}$ has 340 employees in its production site. Of them, roughly $60 \%$ are Portuguese and $40 \%$ are spanish. The company offers above-average wages. The workers are nonunionized and there is a very low labor turnover rate. The workers are responsible for quality control, and management encourages teamwork. The company estimates that the number of production workers will increase due to the expansion of the 
company, development of new products, and the opening of new markets.

The interviews uncovered that all five firms basically are satisfied with labor performance. Both management and labor wish to have a long time relationship. This is reflected by the willingness of the companies to hire permanent workers and the willingness of employees to stay with the companies, as evidenced by low labor turnover rates, with some workers remaining for 30 years. The wage scale in general is relatively stable with annual increases based on the company's performance.

\subsection{Specialization Ratio, Labor Turnover Rate and Change of Geographical Distribution of the Industry}

Historical data on specialization ratios $^{8}$ collected from the Census of Manufactures are tabulated in Table 5.1. During the past two decades, the industry actually has slightly increased its specialization ratio. The most obvious example was SIC 3842 (surgical appliances and supplies) which increased its specialization ratio from 79 to 90 from 1972 to 1987. This means that the industry in general has concentrated relatively more efforts on manufacturing products related to

${ }^{8}$ The specialization ratio represents the ratio of primary product shipments to total product shipments (primary and secondary, excluding miscellaneous receipts) for the establishments classified in the industry (USDC, 1977:A-4). It is intended to measure how company specialize in their industry to which it claims to be belonged. However, limitation about this measurement exists. It can not measure how the company's flexibility through the use of same production technique to produce different products. 


\section{Table 5.1}

Specialization Ratio for the Medical Supply Industry

\begin{tabular}{rrrrr}
\hline SIC CODE & 1972 & 1977 & 1982 & 1987 \\
\hline 3693 & 95 & 98 & 96 & - \\
3841 & 90 & 88 & 90 & 92 \\
3842 & 79 & 87 & 86 & 90 \\
3843 & 93 & 92 & 95 & 94 \\
3844 & - & - & - & 95 \\
3845 & - & - & - & 94 \\
\hline
\end{tabular}

Source: Computed from The Census of Manufactures, 1972, 1977, 1982 and 1987, US Dept. of Commerce, Bureau of Census. 
the medical instruments and supply. It seems to imply that while big firms are penetrating drug markets, certain proportion of the industry's companies still focus on the production of the medical products.

The number of production workers by season in the industry are tabulated in Table 5.2. Between 1972 and 1987 , seasonal variability in the number of production workers in the industry decreased. The coefficient of variation' for the industry's seasonal employment dropped from 2.57 to 0.75 during the period.

Information on the change of the geographical distribution of medical supply industry with regard to establishments, number of employees, and value added is presented in Tables $5.3(\mathrm{a}), 5.3(\mathrm{~b})$ and $5.3(\mathrm{c})$. The West increased its share of establishments, from $24 \%$ in 1972 to $28.4 \%$ in 1987. Total employment increased from $14.46 \%$ to 29.62\% during the same period, and value added increased from $6.1 \%$ in 1977 to $22.1 \%$ in 1987 . In contrast, the Northeast, North Central, and South regions have reduced shares in the national medical supply industry, judging from the number of

The coefficient of variation is calculated as the standard deviation divided by the mean and multiplied by 100 . Therefore, it overcomes the weakness of standard deviation measure which does not take the magnitude of the variable into consideration. The coefficient of variation measures dispersion, in this case, the seasonal variability of the number of the production workers in the industry. However, this measurement does not take any business cycle, union policy and company policy into account, which all influence the seasonal variability of the number of production workers. 
Table 5.2

Nurber of Production Worter in the Modicel Supply laduntry (in Thounandw)

\begin{tabular}{|c|c|c|c|c|}
\hline IC3693 & 193 & 1932 & $19 \pi$ & 1972 \\
\hline Narb & 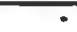 & $22 \pi$ & 1660 & 600 \\
\hline May & - & 2200 & 1690 & 680 \\
\hline Aupow & - & 23.00 & 17.20 & 7.10 \\
\hline Nowneber & - & 23.00 & 17.60 & 7.30 \\
\hline Mean & - & 2200 & 17.08 & 695 \\
\hline SD & - & a.14 & Q.43 & a.31 \\
\hline CV & - & a61 & 252 & 4.46 \\
\hline \multicolumn{5}{|l|}{ Sc341 } \\
\hline Mard & $\mathbf{4 5 0}$ & 360 & 2200 & 200 \\
\hline May & $\$ 5.20$ & 3490 & 29.00 & 24.20 \\
\hline Argant & 45.20 & 3840 & 29.40 & 2430 \\
\hline Nowember & 45.20 & 37.90 & 29.30 & 25.10 \\
\hline Mean & 45.30 & 32.45 & 29.18 & 24.35 \\
\hline SD & a.20 & 0.42 & Q.20 & o.s4 \\
\hline CV & a.4 & 1.09 & 069 & 222 \\
\hline \multicolumn{5}{|l|}{ SC 3842} \\
\hline Mard & 5020 & 47.00 & 3600 & 2200 \\
\hline May & 5080 & 46.20 & 3640 & 29.70 \\
\hline Augara & saso & 45.80 & 3690 & 3000 \\
\hline November & $\$ 230$ & 45.40 & 3680 & 31.00 \\
\hline Mean & 51.05 & 46.10 & 36.53 & 29.93 \\
\hline SD & 0.89 & 068 & a41 & 0.83 \\
\hline $\mathrm{CV}$ & 1.74 & 1.48 & 1.12 & $2 \pi$ \\
\hline \multicolumn{5}{|l|}{ sc 3843} \\
\hline Mard & 260 & 1000 & $10 \%$ & 230 \\
\hline May & 260 & 9.90 & $10 \times 0$ & Lso \\
\hline Augart & 270 & 9.80 & $10 x 0$ & 250 \\
\hline Nowember & 280 & 9.40 & 10.50 & 260 \\
\hline Meas & 268 & 9.78 & 10.65 & 248 \\
\hline SD & 0.10 & 0.26 & 0.10 & 0.12 \\
\hline CV & 1.15 & 206 & asy & 1.42 \\
\hline STC 384 & 1937 & 1932 & 197 & 197 \\
\hline Mard & 5.40 & - & - & - \\
\hline May & 5.50 & - & - & - \\
\hline Augual & 5.40 & - & - & - \\
\hline Nowember & 5.40 & - & - & - \\
\hline Mean & 5.43 & - & - & - \\
\hline SD & 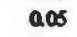 & - & - & - \\
\hline CV & $a x$ & - & - & - \\
\hline \multicolumn{5}{|l|}{ Sc 395} \\
\hline Mad & 13.20 & - & $\cdot$ & - \\
\hline May & 13.10 & - & - & - \\
\hline Augent & 13.10 & - & - & - \\
\hline November & 13.30 & - & - & - \\
\hline Mean & 13.18 & - & - & . \\
\hline SD & a.10 & - & - & - \\
\hline CV & ax & - & $=$ & - \\
\hline \multicolumn{5}{|l|}{ Tal } \\
\hline Marcb & 123.00 & 11830 & 9230 & $67 . \pi 0$ \\
\hline May & 123.20 & 117.90 & 93.00 & 09.20 \\
\hline Augest & 123.30 & 117.00 & 9.20 & 09.90 \\
\hline Novenber & 125.00 & 115.70 & 9420 & $\mathbf{n} 00$ \\
\hline Mean & 123.63 & 117.23 & 93.43 & 0.70 \\
\hline SD & 0.93 & 1.15 & a94 & 1.79 \\
\hline CV & 0.75 & ass & 1.01 & 257 \\
\hline
\end{tabular}

Note: SD stendard Deviation; CV-Coeficiest of Variation.

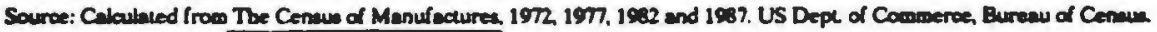


Table 5.3(n)

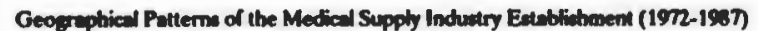

\begin{tabular}{|c|c|c|c|c|c|c|c|c|c|c|c|c|c|c|c|c|c|c|c|c|c|}
\hline $\operatorname{siccod}$ & & $363^{\circ}$ & & & 391 & & & & $\sin 2$ & & & & 3243 & & & $334^{\circ}$ & $3045^{\circ}$ & & $\sec 5$ & & \\
\hline Region & $19 n$ & 197 & 1982 & 1972 & $19 \pi$ & 1982 & 1987 & 1972 & 1977 & 1982 & 1907 & $19 \mathrm{~m}$ & $19 m$ & 1902 & 1987 & 1987 & 1987 & 1922 & $19 m$ & 1902 & 1987 \\
\hline NORTHEAST & 43 & 79 & 74 & 204 & 220 & 256 & 305 & 257 & 291 & 362 & 370 & 136 & 148 & 125 & 111 & 19 & 58 & 600 & 736 & 817 & 863 \\
\hline \% of Tot & 41 & 33 & 28 & $\infty$ & $\mathbf{m}$ & 30 & 27 & 29 & 25 & 26 & 25 & 32 & 27 & 26 & $\boldsymbol{n}$ & 25 & 26 & 33 & 28 & 27 & 25 \\
\hline New Englend & 12 & 31 & 35 & $n$ & 76 & 93 & 110 & 62 & 8 & 110 & 104 & 15 & 17 & 19 & 10 & 10 & 24 & 161 & 212 & 257 & 258 \\
\hline Middre Allennic & 31 & 46 & 39 & 132 & 144 & 163 & 195 & 195 & 200 & 252 & 266 & 121 & 131 & 106 & 101 & 9 & 34 & 479 & 526 & 560 & $\cos$ \\
\hline NORTH CENTRAL & 25 & 4 & 53 & 123 & $15 t$ & 190 & 242 & 230 & 282 & 326 & 363 & 102 & 9 & 6 & $\mathbf{z}$ & 20 & 50 & 486 & 580 & 658 & 757 \\
\hline \% of Toul & 24 & 20 & 20 & 24 & 23 & 22 & 21 & 27 & 24 & 24 & 24 & 24 & 10 & 18 & 16 & 27 & $\mathbf{2 2}$ & 26 & $\boldsymbol{n}$ & 22 & 22 \\
\hline E North Centrol & 22 & 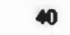 & 40 & 85 & 101 & 128 & 166 & 173 & 217 & 246 & 27 & 76 & 4 & 75 & 66 & 20 & 34 & 350 & 442 & 409 & 560 \\
\hline w. North Central & 3 & 9 & 13 & 36 & so & 62 & 76 & 65 & 65 & 80 & 91 & 24 & 14 & 14 & 14 & - & 16 & 130 & 138 & 169 & 197 \\
\hline SOUTH & 6 & 47 & 42 & $\omega$ & 95 & 129 & 202 & 210 & 262 & 319 & 309 & so & 11 & 32 & $\infty$ & 4 & 34 & 335 & 415 & $\mathbf{5 2 2}$ & $\cos$ \\
\hline \%o of Tout & 6 & 19 & 16 & 14 & 15 & 15 & 10 & 24 & 23 & 23 & 26 & 12 & 2 & 7 & 13 & 5 & 15 & 18 & 16 & 10 & 20 \\
\hline S. Allontic & 5 & 13 & 24 & 40 & 47 & 73 & 119 & 115 & 124 & 109 & 220 & 30 & 5 & 29 & 46 & 4 & 18 & 190 & 169 & 315 & $\infty n$ \\
\hline E South Centrad & - & $x$ & & 11 & 11 & 3 & 18 & 37 & $\$ 1$ & 60 & 67 & - & 6 & 3 & 3 & - & & 40 & $\boldsymbol{r}$ & 66 & 8 \\
\hline W. Sounh Centrol & - & 5 & 10 & 18 & 37 & 53 & 65 & 58 & 87 & 70 & 102 & - & - & - & 17 & - & 16 & 76 & 590 & 141 & 200 \\
\hline WEST & 25 & 6 & 74 & 110 & 140 & 262 & 331 & 168 & 188 & $2 n$ & 315 & 141 & 162 & 135 & 148 & 16 & $\alpha$ & $\omega$ & 567 & 740 & 87 \\
\hline Tof Total & 24 & 28 & 28 & 22 & 23 & 31 & 29 & 19 & 16 & 20 & 21 & 33 & 29 & 28 & 20 & 21 & 28 & 23 & 22 & 25 & 25 \\
\hline Mountsin & 3 & 9 & 12 & 13 & 11 & 46 & 57 & 28 & 25 & 53 & 63 & 20 & 10 & 12 & 10 & 3 & 9 & 64 & 55 & 123 & 142 \\
\hline Pecific & 22 & 59 & 62 & 97 & 138 & 216 & 274 & 140 & 163 & 224 & 252 & 121 & 152 & 123 & 138 & 13 & 53 & 300 & 512 & 625 & T30 \\
\hline USA & 104 & 243 & 261 & 506 & 600 & 659 & 1136 & 873 & 1153 & 1367 & 1500 & 429 & 530 & $\cos$ & son & 75 & 224 & 1912 & $25 \%$ & $29 m$ & 3439 \\
\hline
\end{tabular}

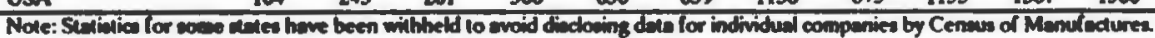

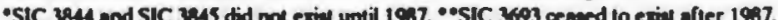

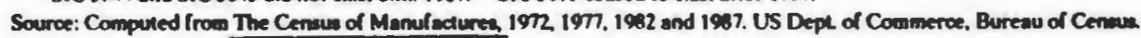


Table 5.3(b)

Geogrephical Patterne of the Medical Supphy Induatry by Employmext in Thounand

\begin{tabular}{|c|c|c|c|c|c|c|c|c|c|c|c|c|c|c|c|c|c|c|c|c|c|}
\hline \multirow{2}{*}{$\begin{array}{l}\text { Siccade } \\
\text { Revion }\end{array}$} & \multicolumn{3}{|c|}{$3653^{\circ}$} & \multicolumn{3}{|c|}{394} & \multicolumn{4}{|c|}{3042} & \multicolumn{4}{|c|}{3643} & \multicolumn{2}{|c|}{ 360 } & \multicolumn{2}{|l|}{$35015^{\circ}$} & \multicolumn{2}{|l|}{34} & \multirow[b]{2}{*}{1907} \\
\hline & $19 n$ & $19 \pi$ & 19.32 & $19 n$ & $19 \pi$ & 19,02 & 1907 & $19 \pi$ & $19 \pi$ & 1962 & 1907 & $19 m 2$ & $19 n$ & $\tan 2$ & 1907 & 1907 & 1987 & $19 n$ & $19 n$ & 1902 & \\
\hline NORTHEAST & 26 & 106 & 127 & 163 & 17.3 & 16.3 & 20.8 & 17.4 & 18.9 & 24.9 & 21.9 & 5.4 & 6.3 & 3.6 & a.4 & 29 & 21 & 41.7 & 53.1 & 59.4 & 581 \\
\hline Not Toed & 21.5 & 34.3 & 26.5 & 47.2 & 40.0 & 28.6 & 20.5 & 39.5 & 35.3 & 362 & 27.9 & 43.5 & 38.5 & 35.8 & 308 & 33.7 & 27.6 & 39.9 & 369 & 31.4 & 24.6 \\
\hline New England & as & 5.8 & 7.9 & 6.2 & 5.4 & 6.7 & 11.0 & 3.1 & 4.9 & 66 & 5.8 & 0.6 & 06 & 1.0 & a6 & 1.5 & 3.8 & 107 & 167 & 22.1 & 226 \\
\hline Mid. Altontic & 1.9 & 4.8 & 4.8 & 10.2 & 11.9 & 9.6 & 9.8 & 14.4 & 14.0 & 123 & 16.1 & 4.9 & 5.7 & 4.6 & 3.8 & 1.5 & 4.3 & 31.4 & 364 & 37.3 & 35.4 \\
\hline NORTH CENTRAL & 60 & 7.7 & 10.8 & $\mathbf{2 3}$ & las & 14.1 & 14.5 & 11.5 & 16.0 & 17.9 & 18.9 & 3.1 & 3.5 & 5.8 & 3.3 & 13 & 5.7 & 229 & 37.6 & 486 & 45.6 \\
\hline \%of Tolef & 49.6 & 24.8 & 227 & $2 a .1$ & 24.3 & 24.7 & 19.8 & 26.1 & 29.8 & 200 & 241 & 25.0 & 21.7 & 37.4 & 22.8 & 37.4 & 19.5 & 20.1 & 26.1 & 25.7 & 224 \\
\hline E. N. Centrel & 5.0 & 4.9 & 20 & 5.3 & 5.1 & 7.5 & as & 9.8 & 11.9 & 11.8 & 121 & 25 & 3.3 & 3.2 & 29 & 33 & 3.1 & 226 & 25.2 & 30.4 & 29.9 \\
\hline W. N. Cemrest & 1.0 & 28 & 29 & 3.0 & 5.4 & 6.6 & 6.0 & 1.8 & 4.1 & a.1 & 68 & 06 & $a_{2}$ & 26 & $a_{4}$ & - & 26 & 64 & 124 & 18.2 & 15.7 \\
\hline south & 1.8 & 4.4 & 6.2 & 4.9 & 4.9 & 12.3 & 14.8 & 100 & 100 & 14.0 & 21.8 & 1.0 & ab & 1.7 & 21 & ab & 23 & 17.7 & 19.8 & 34.2 & 41.5 \\
\hline \% of Toum & 14.5 & 14.1 & 129 & 14.2 & 11.3 & 21.7 & 20.3 & 227 & 187 & 203 & 27.7 & Q1 & 3.6 & 11.0 & 14.7 & 67 & 7.8 & 17.1 & 13.8 & 10.1 & 204 \\
\hline S. Altemtic & 1.8 & 3.6 & 4.2 & 29 & 3.8 & 27 & 8.8 & 5.1 & 5.5 & 7.7 & 11.0 & as & $a_{4}$ & 1.3 & 1.7 & as & 1.7 & 106 & 13.3 & 220 & 238 \\
\hline E.S. Centrel & - & & & 0.9 & a.2 & 0.2 & 1.1 & 3.2 & 20 & 29 & 5.8 & - & a.2 & a4 & a.2 & - & & 41 & 24 & 3.5 & 7.1 \\
\hline W.S. Central & - & 0.8 & 20 & 1.1 & 1.0 & 3.4 & 4.9 & 1.8 & 25 & 3.4 & 5.0 & - & - & - & $a_{2}$ & $\overline{-}$ & 1.6 & 29 & 4.2 & 28 & 11.6 \\
\hline WEST & 1.8 & 4.5 & 14.1 & 4.9 & 11.1 & 16.4 & 189 & 5.1 & 7.5 & 120 & 125 & 28 & 4.1 & 3.6 & 3.9 & 1.9 & 11.8 & 14.6 & 27.2 & 4a) & 48 \\
\hline Tof Tout & 14.5 & 14.7 & 29.6 & 14.2 & 25.7 & 20.6 & 25.8 & 11.6 & 14.0 & 17.4 & 15.9 & 22.6 & 24.8 & 232 & 2699 & 21.6 & $\$ 0.4$ & 14.1 & 189 & 24.4 & 240 \\
\hline Mountming & & 1.0 & 3.6 & as & 3.3 & 5.1 & 5.0 & 0.8 & ab & 21 & 23 & 0.8 & a. & as & a.4 & 1.1 & 23 & 20 & 5.6 & 11.3 & 11.0 \\
\hline Pecolic & 1.8 & 3.6 & Ias & 4.4 & 7.9 & 11.3 & 13.9 & 1.4 & 69 & 9.9 & 102 & 21 & 3.3 & 3.1 & 3.5 & as & 9.5 & 126 & 21.6 & 34.8 & 37.8 \\
\hline USA & 121 & 30.9 & 47.7 & ins & 43.2 & 569 & 3.1 & $\mathbf{4 0}$ & 53.5 & 608 & 70.5 & 124 & 163 & 15.5 & 14.3 & 27 & 29.2 & 108.0 & 143.9 & 1809 & 20038 \\
\hline
\end{tabular}


Tnble 5.3(c)

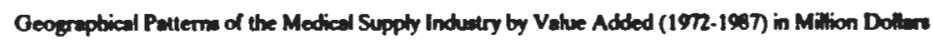

\begin{tabular}{|c|c|c|c|c|c|c|c|c|c|c|c|c|c|c|c|c|c|c|c|c|c|}
\hline SIC Code & & $363^{\circ}$ & & & 3041 & & & & 3612 & & & & 3843 & & & $34^{\circ}$ & $3645^{\circ}$ & & & 364 & \\
\hline Region & 1972 & 197 & 1962 & $19 m$ & $19 \pi$ & 1962 & 1987 & 197 & $19 n$ & 1982 & 1987 & 1972 & 197 & 1982 & 1987 & 1987 & 1987 & 1972 & $19 \pi$ & 1902 & 1987 \\
\hline NORTHEAST & - & 4526 & 587.6 & 292.7 & 374.2 & 584.9 & 1413.8 & 357.7 & 4586 & 1000.1 & 196.8 & 122.3 & 173.5 & 19,08 & ses & 901 & 136.5 & $\mathbf{m . 7}$ & 14589 & 2451.4 & 19460 \\
\hline \% of Toual & - & 24.0 & 21.3 & 46.5 & 309 & 20.3 & 27.2 & 38.4 & 28.9 & 31.5 & 3.6 & 4.6 & 37.8 & 29.7 & $\$ 1.2$ & 11.8 & 5.8 & 362 & 20.4 & 25.3 & 13.2 \\
\hline New England & & 238.2 & 460.2 & 110.9 & 602 & 151.4 & 873.7 & 469 & 29.2 & 170.0 & $n .7$ & 10.1 & 4.1 & 3.7 & 369 & 260 & 1305 & 167.9 & 331.7 & $m 5.3$ & 1147.8 \\
\hline Middle Allentic & - & 234.4 & 127.4 & 181.8 & 314.0 & 433.5 & 540.1 & 310.3 & 429.4 & 9181 & 126.1 & 112.3 & 169.4 & 187.1 & 59.9 & 7.1 & - & $\cos 4.4$ & 1127.2 & 1661 & 72 \\
\hline NORTH CENTRAL & 161.1 & 213.4 & 405.1 & 169.4 & 99.0 & 237.6 & 399.2 & 2827 & 44.2 & 847.6 & 1105.0 & 64.4 & 66.2 & 100.3 & - & - & 253.6 & 677.6 & 0228 & 1672.6 & 19520 \\
\hline$\%$ of Tall & 51.8 & 11.3 & 14.8 & 26.9 & 82 & 8.2 & 11.4 & 304 & 28.0 & 24.6 & 20.3 & 24.6 & 14.4 & 28.0 & & - & 10.7 & 31.7 & 160 & 17.2 & 13.3 \\
\hline E. N. Central & - & 183.0 & 405.1 & 99.7 & 54.6 & 172.2 & 400.8 & - & 366.3 & moa.3 & 811.3 & - & 61.5 & 65.6 & $\overline{-}$ & - & 200.4 & 99.7 & 607.4 & 1343.4 & 1423.5 \\
\hline W. N. Central & - & 30.4 & _- & 69.7 & 4.4 & 65.4 & 184.4 & - & 55.9 & 147.1 & 293.7 & - & 4.7 & 114.7 & - & - & sat & 69.7 & 135.4 & 327.2 & s28s \\
\hline SOUTH & - & 124.5 & 15.7 & 67.7 & 462 & 285.2 & 587.9 & 205.8 & 126.7 & 3269 & 847.0 & 20.3 & - & 3.8 & - & - & 107.2 & 293.8 & 297.4 & 631.6 & 15421 \\
\hline \% of Tad & - & 6.6 & 0.6 & 107 & 3.8 & 9.9 & 11.3 & 221 & 8.0 & 9.5 & 15.6 & 7.7 & - & a.6 & - & - & 4.5 & 13.8 & 5.8 & 6.5 & 105 \\
\hline South Altwotic & & 124.5 & 7.1 & 39.4 & 46.2 & 127.9 & 437.9 & 84.0 & 78.6 & 95.0 & 4967 & 164 & - & 3.8 & $\overline{-}$ & - & _ & 139.8 & 209.3 & 233.8 & 934.6 \\
\hline E. S. Central & $z$ & - & & 13.6 & - & & 4.9 & - & 48.1 & & & - & - & - & $=$ & $=$ & & 13.6 & 46.1 & ao & 4.9 \\
\hline W. S. Central & - & - &.$\overline{6}$ & 14.7 & - & $157 . \overline{3}$ & 145.1 & - & _- & 231.9 & $350 \overline{3}$ & - & - & - & - & $=$ & $107 . \overline{2}$ & 14.7 & $a_{0}$ & 397.8 & 6026 \\
\hline WEST & _ & 115.8 & 602.4 & 100.2 & 167.4 & 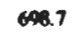 & 1175.7 & 85.0 & 187.8 & 447.5 & 900.0 & 55.3 & 97 & 1721 & 14.3 & - & 759.9 & 2 ans & 567.7 & $192 a 7$ & 2049.9 \\
\hline Xof Toul & $\overline{-}$ & 6.1 & 22.1 & 15.9 & 13.8 & 24.2 & 226 & 9.1 & 11.8 & 13.0 & 165 & 21.1 & 21.1 & 268 & 1.6 & 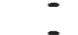 & 321 & 11.3 & 11.0 & 19.8 & 19.3 \\
\hline Mountsin & & 25.3 & 100.2 & 10.7 & & 178.9 & 105.1 & 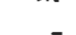 & 19.3 & 45.3 & 134.9 & - & & 189 & 14.3 & - & $17 n .5$ & 107 & 4.6 & 343.3 & 431.8 \\
\hline Pacific & - & 90.5 & 502.2 & 89.5 & $167 \overline{4}$ & 519.8 & 1070.6 & $\overline{-}$ & 168.5 & $\$ 022$ & 765.1 & - & $9 \overline{7}$ & 153.2 & - & - & 5824 & 89.5 & 523.1 & 1577.4 & 24181 \\
\hline USA & 311.3 & 1884.7 & 2728.8 & 6300 & 12122 & 2804.8 & 52022 & 930.7 & 15864 & 3450.8 & 5443.7 & 2623 & 4586 & G12: & 800.7 & 834.5 & 2360.8 & 2134.3 & 5141.9 & 9707.2 & ....... \\
\hline
\end{tabular}


establishments, total employment and value added. ${ }^{10}$ National change of population distribution may partly explain this regional shift. The West has increased its share of the national population from 18.348 to 20.428 from 1977 to 1987 (Table 5.4), while the Northeast and North Central regions both decreased their shares of the national population.

5.4 Is Flexibility Occurring in the Medical supply Industry? Using the definition of flexibility as a term indicating a spatially dense network of related small, vertically disintegrated firms with small batch production, this section argues that while the medical supply industry has some manifestations of flexibility, the whole industry cannot be considered "flexible". The reasons are substantiated as follows.

\section{4 .1 Industry strategies}

In general, the strong performance of the medical supply industry during the past two decades is attributable to its innovative strategies for coping with the changing environment. These strategies can be grouped into three types: 1) continual technological innovation to make products more competitive; 2) targeting new markets, such as non-hospital markets, geriatric markets, drug markets, and foreign markets

10 With the exception of the south increasing its share of establishments from $5.77 \%$ in 1972 to $16.1 \%$ in 1987 , and the Northeast increasing its share in total employment from $21.49 \&$ to $26.52 \%$ during the same period of time. 
Table 5.4

Population by Regions (in Thousands) 1977-1987

\begin{tabular}{lrrr}
\hline Region & 1977 & 1982 & 1987 \\
\hline & 49282 & 49304 & 50301 \\
NORTHEAST & 22.43 & 21.27 & 20.66 \\
\% of Total & 12239 & 12428 & 12845 \\
New England & 37043 & 36876 & 37456 \\
Middle Atlantic & & & \\
& 58363 & 58926 & 59547 \\
NORTH CENTRAL & 26.56 & 25.42 & 24.46 \\
\% of Total & 41381 & 41582 & 41923 \\
E. North Central & 16982 & 17344 & 17624 \\
W. North Central & & & \\
& 71816 & 78438 & 83880 \\
SOUTH & 32.68 & 33.84 & 34.46 \\
\% of Total & 35293 & 38307 & 41708 \\
S. Atlantic & 14236 & 14862 & 15288 \\
E. South Central & 22287 & 25269 & 26884 \\
W. South Central & & & \\
& 40299 & 45152 & 49698 \\
WEST & 18.34 & 19.48 & 20.42 \\
\% of Total & 10402 & 12068 & 13171 \\
Mountain & 29897 & 33084 & 36527 \\
Pacific & & & \\
& 219760 & 231822 & 243427 \\
\hline USA & Source: Computed from Statistical Abstract of the United States, 1986 and 1991. \\
\cline { 2 - 2 } &
\end{tabular}


to gain more profit; 3) innovative contract strategies to maintain market share. While the first two strategies are related to flexibile specialization, these strategies are not being implemented through small firm production, small batch production, or agglomerated firms as would be the case with flexible specialization.

\subsubsection{The Production Process}

Although the industry in general has made tremendous efforts to introduce new technologies and new product process innovations, many firms still manufacture devices or equipment using old fashioned methods. The flexibility thesis' argument that high-tech is heavily involved in the production process is not an appropriate characterization of this case.

However, the industry seems to show a new form of flexibility. This new form of flexibility is characterized by firms using unsophisticated, easy to operate machines to produce different products. Many small firms use this strategy to achieve success as niche players. This opens another channel to look at the whole flexibility debate.

\section{4 .3 Firm 8ize}

National data indicate the medical supply industry consists mainly of small and medium-sized establishments (see Table 4.2). About 878 of firms in the industry employ less than 100 people. Of the five firms interviewed, four employed fewer than 100 persons. However, these firms' small size is not recent. Some of these firms were founded as a family 
business, while other were founded for the production of a single product. All were established long before the claimed shift to flexible specialization occurred. To argue that flexibility has led to an increase in the number of small and medium-sized establishments would be a misinterpretation.

\section{4 .4 Location Factor}

Although national data (see Table $5.3(a), 5.3(b), 5,3(c)$ ) indicate the West region increased its share in the industry during the past two decades, location is not very important in the industry's decision-making process. The broad locational decisions of the firms interviewed were based more on historical legacies, availability of new facilities, and personal ties. However, two things the firms share are availability of good labor and proximity to Boston, the predominant medical R\&D center. In other words, the firms may agglomerate but not for the convenience of sharing information as the flexibility theory suggests.

\subsubsection{The Labor Process}

According to national data, the seasonal variability of the number of employees in the industry has dropped during the past two decades (see Table 5.2). The interviews further support this finding. Relations between labor and management are generally harmonious. Both sides prefer to maintain long time, stable, friendly relationships. This is evidenced by low 
labor turnover rates ${ }^{11}$ which contradicts the claim that flexible labor processes are characterized by more part-time workers and high labor turnover rates.

Moreover, wage scales for the companies interviewed are relatively stable. Many of companies stated that they have an above-average wage. This again contradicts the claim of wages becoming more flexible or being low.

In summary, the medical supply industry has successfully coped with different factors during the past two decades. Although the industry has shown some signs of flexibility, it cannot be considered as "flexible specialized". For example, the firms do achieve flexibility by using multipurpose machines to produce different products for different markets. Small and medium-sized firms are prevalent, but this has been an historical phenomenon. Firms do agglomerate to gain access to good labor and medical R\&D centers, but not for sharing information. Most firms have low labor turnover rates and above-average wages. This is not the case flexible specialization claims.

11 Some workers in some firms we interviewed have stayed in the firm for 30 years. 


\section{Chapter $\mathrm{Bix}$}

\section{Policy Implications}

Unlike the textile finishing industry (Nisbet, 1991), the medical supply industry has undergone substantial growth during the last two decades. It has created many jobs and has a substantial trade-surplus. The industry is expected to continue growing in the years ahead (S\&P, 1991). The success of this industry is based on its continued involvement in developing new products and new methods of production; recruiting, maintaining and continuously training a good and stable workforce; strong marketing efforts, both domestically and internationally; achieving "flexibility" by using multipurpose machines to produce different products for different markets. What we have learned is of significance for policy-making. Several recommendations following the analysis are presented.

First of all, to maintain economic growth and stability and to increase income, government should invest more in R\&D programs in the medical supply industry since the success of the industry is mainly based on its leading position in introducing new products and new technologies. Moreover, the industry has to face more and more intensive challenges from competitors in other developed countries, such as Japan and the West European countries, which receive a considerable amount of government financial assistance in 
developing new products and new technologies (S\&P, 1991) ${ }^{12}$. Specific policies include three areas. First, government should allocate funds for R\&D programs in the medical supply industry through budgeting. This could be achieved through direct investment in the industry or by providing loan guarantees to companies. This would enable the U.S to maintain its competitive edge in the market place.

Secondly, investments in R\&D should be intentionally concentrated among universities, research institutions, hospitals, medical schools and those medical supply companies involved in R\&D. Special attention should be given to those organizations which are spatially concentrated thereby creating centers for research and applications of medical devices. As evidenced by the interviews, all firms clustered around the Boston area are able to react quickly to the changes in product requirements and new technological developments.

Thirdly, a commission should be formed which would evaluate and monitor R\&D programs in terms of their effectiveness and viability. The commission would also develop a strategic plan, manage the budget, and address specific issues in R\&D programs associated with the industry. Special focus should be given to a product's growth potential, amount of value-added, compatibility with labor force skills,

12 This concern was also expressed by some of the managers interviewed for this project. 
compatibility with the environment, and job generating potential.

The second recommendation relates to labor. As evidenced by the interviews, companies have stayed in New England principally because of the availability of good labor with metal-working experience. However, with continual technological innovation being the key to success in the medical supply industry, the industry will need to move beyond simple machine shop operations to remain competitive. Therefore, upgrading the local labor force with more advanced machining skills will help both the industry and the region remain competitive.

Several specific policies follow. First of all, government should encourage traditional training institutions, such as technical training programs and community colleges, and new training schools to contract with private industry in developing, planning, and designing training programs and curricula that will meet the industry's anticipated needs. This is extremely crucial for training requiring specialized equipment, facilities or experienced trainers.

Secondly, government should pursue long term training contracts between the industry and job training institutions, thereby encouraging the industry to hire program graduates. Moreover, government should promote information exchanges between the industry and job training institutions. As we 
found in the interviews, some firms have experienced difficulties in finding good labor.

Thirdly, government should encourage employers to provide a commitment to child care options for their employees by providing child-care support in the employee benefits package, as well as locating day care facilities near or in the work place. From our interviews, due to the unique feature of the industry, we found firms in the industry hire considerable number of workers who are in their 20 s to 40 s. Providing child care facilities will release the double burden on working parents and thereby improve the availability of labor.

Last but not least, policy should support small and medium-sized businesses. As we discovered in our analysis, the medical supply industry consists mainly of these companies. These companies contribute to the economy through their successful operation as niche players. These small businesses are an important source for the growth and stability of the economy. However, these firms also experience different pressures and difficulties. Some lack financial ability--, Many do not issue public stock--, and few have long-term plans. Therefore, compared with large firms, small businesses have less ability to pass on cost due to inflation, and have difficulty investing in the development of new products and new technology, and are less able to deal with 
the continually complicated legislation concerning the industry.

Government could assist these firms in at least the following ways. First of all, government could support and assist small business with start-up and expansion by providing technical and information resources and by aiding in capital formation through low interest loans. Secondly, government could provide technical assistance, helping businesses to identify problems and solutions before problems become severe, and assist in the development of stabilization and expansion plans with realistic background information and figures. Thirdly, government should assist small business in fulfilling legal requirements. Many small firms interviewed complained about red-tape and tedious procedures in dealing with government regulations. Complex procedures have made it necessary for small firms to hire personnel solely for dealing with legal issues. However, not all small firms can afford to do this. Therefore, a coordinated effort by government to assist these small firms could certainly enhance the competitiveness of the firms and improve the profit rate of the firms. For example, government could create legal coordinator(s) to provide information on legal issues and to help small firms solve any regulatory problems.

The flexibility debate also impacts planning as a discipline. First, the flexibility debate undoubtedly enhances the academic development of planning by adding another piece 
of knowledge to our understanding of how communities and regions develop.

Second, the flexibility debate would also impact planning education because of its implicit challenge to some forms of planning education. Should planning students be required to know more about political economy and industrial organization? What background knowledge should planning students possess to deal with more and more complex planning issues? All in all, these are the questions that planning educators must face. 


\section{Bibliography}

Albrechts, Louis \& Swyngedouw, Erik. 1988. The Challenges for Regional Policy Under a Flexible Regime of Accumulation, Regional Policy of the Crossroads, Jessica Kingsley \& Rogan Paul, London.

Amin, Ash. 1989. Flexible specialization and Small Firms in Italy: Myths and Realities, Antipode, 21:1.

Feldman, Marshall M. A. 1989a. Technological Change, Industrial Organization and the Restructuring of united states Manufacturing, Prepared for the International symposium on Regulation, Innovation and Spatial Development, University of Wales, Cardiff, UK September 13-15, 1989.

1989b. The Flexibility Thesis and Vertical University of Rhode Island.

1989c. Flexible Production: Its Incidence and Implications for Labor Markets and Economic Development Strategy, Research Proposal Submitted to the Research and Evaluation Program Economic Development Administration, U.S. Department of Commerce, University of Rhode Island.

Feldman, Marshall M. A. \& Mullin, John R. 1988. Industrial organization and Rural Economic Development: Two Case studies in the Blackstone Valley, Research Proposal submitted to the Northeast Regional Center for Rural Development.

Feldman, Marshall M. A. and Yuan, Huaqi. 1990. Industrial Organization and National Metropolitan Development. Paper for 32nd Annual Conference of ACSP, November 2-4, 1990.

Florida, Richard L. and Feldman, Marshall M. A. 1988. Housing in US Fordism. International Journal of Urban and Regional Research. 12,2 (June) 1988.

Harvey, David. 1989. The Condition of Postmodernity. Basic Blackwell, oxford.

Malecki, Edward J. 1985. Industrial location and corporate organization in high technology. Economic Geography 61,4 (October): 345-69.

Nisbet, Alison K. 1991. The Textile Finishing Industry in New England: Is Flexible Specialization Occurring?. Unpublished MCP Research Project, Department of Community Planning and Area Development, The University of Rhode Island. 
Piore, Michael J. \& Sabel, Charles F. 1984. The Second Industrial Divide: Possibilities for Prosperity, Basic Books, Inc., New York.

Sabel, Charles F. 1988. Flexible specialization and the ReEmergence of Regional Economies, in Reversing Industrial Decline, ed. Paul Hirst and Jonathan Zeitlin. Oxford, Berg.

Sabel, Charles F. \& Zeitlin Jonathan, 1985. Historical Alternatives to Mass production: Politics, Markets and Technology in Nineteenth-Century Industrialization. Past and Present 108, August, pp 133-176.

S\&P, see Standard and Poor's Corporation.

Sayer, Andrew. 1987. Postfordism in Question, International Journal of Urban and Regional Research, 13.

Schoenberger, E. 1988. From Fordism to Flexible Accumulation: Technology, Competitive strategies, and International Location, Environment \& Planning D: Society \& Space, Vol. 6 pp. 245-262.

Scott, A. J. 1987. The Semiconductor Industry in South-East Asia: Organization, Location and the International Division of Labour. Regional studies. Vol. 21,2 pp. 143-160.

- 1988. Flexible Production Systems and Regional Development: The Rise of New Industrial spaces in North America and Western Europe. International Journal of Urban and Regional Research 12,2 (June).

Scott, A.J. \& Angel, D. P. 1987. The US Semiconductor Industry:- A Locational Analysis. Environment and Planning A. Vol. 19, pp. 875-912.Standard and Poor's Corporation, 1986. Standard and Poor's Industry Surveys, Medical Equipment and Supplies, New York.

- 1987. Standard and Poor's Industry Surveys, Medical Equipment and supplies, New York.

- 1988. Standard and Poor's Industry Surveys, Medical Equipment and Supplies, New York.

- 1990. Standard and Poor's Industry Surveys, Medical Equipment and supplies, New York.

- 1991. Standard and Poor's Industry Surveys, Medical Equipment and supplies, New York.

Storper, Michael. 1989. Production Flexibility and Regional Development: Current Debates and Controversies, Presentation 
to International Symposium on "Regulation, Innovation, and Spatial Development, Cardiff, Wales.

- 1991. Regional "Worlds of Production:" Conventions of Learning and Innovation in Flexible Production systems of France, Italy, and the USA. Paper for the Annual Meeting of the Association of American Geographers, Miami, April 16, 1991.

USDC, see U.S. Department of Commerce.

U.S. Department of Commerce, Bureau of the Census. 1972 . Census of Manufactures.

- 1977. Census of Manufactures.

- 1982a. Census of Manufactures.

Instruments.

- 1982b. U.S. Industrial Outlook - Medical

- 1984. Annual Survey of Manufactures.

- 1986a. Annual Survey of Manufactures.

Instruments.

1986b. U.S. Industrial Outlook - Medical

- 1986c. Statistical Abstract of the United States.

- 1987a. Census of Manufactures.

Instruments.

1987b. U.S. Industrial Outlook - Medical

- 1989. Annual Survey of Manufactures.

- 1990. U.S. Industrial Outlook - Medical Instruments.

Instruments.

1991a. U.S. Industrial Outlook - Medical - 1991b. Statistical Abstract of the United States.

U.S. Office of Management \& Budget, 1987. Standard Industry Classification Manual. Government Printing office, Washington, DC.

USOMB, see U.S. Office of Management \& Budget. 
Wall Street Journal, 1987. "GE Plan to Acquire Thomson Unit IS Part of Battle for Medical-Imaging Business." July 24 , Sec. C, $2: 3$.

- 1989. "Johnson \& Johnson Patents to Be Peddled Under Unusual Pact." March 13, Sec. B, 3:1.

- 1990a. "Quadra Logic Attracts Big U.S. Partners for Work on New Kind of Cancer Drug." Feb. 20, Sec. C, 6:5.

- 1990b. "Unit Has Five-Year Accord to Supply Mercy Hospitals." Feb. 22, Sec. C, 2:5.

- 1990c. "Bausch \& Lomb Applies an Above-the-Neck Strategy." Feb. 27, Sec. A, 8:1.

WSJ, See The Wall street Journal. 